\title{
Estimated stocks of circumpolar permafrost carbon with quantified uncertainty ranges and identified data gaps
}

\author{
G. Hugelius ${ }^{1}$, J. Strauss ${ }^{2}$, S. Zubrzycki ${ }^{3}$, J. W. Harden ${ }^{4}$, E. A. G. Schuur ${ }^{5,6,7}$, C.-L. Ping ${ }^{8}$, L. Schirrmeister ${ }^{2}$, \\ G. Grosse $^{2}$, G. J. Michaelson ${ }^{8}$, C. D. Koven ${ }^{9}$, J. A. O'Donnell ${ }^{10}$, B. Elberling ${ }^{11}$, U. Mishra ${ }^{12}$, P. Camill ${ }^{13}$, Z. Yu ${ }^{14}$, \\ J. Palmtag ${ }^{1}$, and P. Kuhry ${ }^{1}$ \\ ${ }^{1}$ Department of Physical Geography and Quaternary Geology, Stockholm University, 10691 Stockholm, Sweden \\ ${ }^{2}$ Alfred Wegener Institute Helmholtz Centre for Polar and Marine Research, Periglacial Research Unit Potsdam, \\ Telegrafenberg A43, 14473 Potsdam, Germany \\ ${ }^{3}$ Institute of Soil Science, Center for Earth System Research and Sustainability (CEN), Universität Hamburg, Allende-Platz 2, \\ 20146 Hamburg, Germany \\ ${ }^{4}$ U.S. Geological Survey, Menlo Park, CA 94025, USA \\ ${ }^{5}$ Department of Biology, University of Florida, Gainesville, FL 32611, USA \\ ${ }^{6}$ Center for Ecosystem Science \& Society, Northern Arizona University, Flagstaff, AZ 86001, USA \\ ${ }^{7}$ Biological Sciences, Northern Arizona University, Flagstaff, AZ 86001, USA \\ ${ }^{8}$ Palmer Research Center, University of Alaska Fairbanks, 1509 S. Georgeson Drive, Palmer, AK 99645, USA \\ ${ }^{9}$ Lawrence Berkeley National Lab, Berkeley, CA, USA \\ ${ }^{10}$ Arctic Network, National Park Service, 4175 Geist Rd. Fairbanks, AK 99709, USA \\ ${ }^{11}$ CENPERM (Center for Permafrost), Department of Geosciences and Natural Resource Management, \\ University of Copenhagen, Øster Voldgade 10, 1350 Copenhagen, Denmark \\ ${ }^{12}$ Environmental Science Division, Argonne National Laboratory, 9700 South Cass Avenue, Argonne, IL 60439, USA \\ ${ }^{13}$ Earth and Oceanographic Science Department and Environmental Studies Program, Bowdoin College, Brunswick, \\ ME 04011, USA \\ ${ }^{14}$ Department of Earth and Environmental Sciences, Lehigh University, 1 West Packer Avenue, Bethlehem, PA 18015, USA
}

Correspondence to: G. Hugelius (gustaf.hugelius@natgeo.su.se)

Received: 17 March 2014 - Published in Biogeosciences Discuss.: 26 March 2014

Revised: 26 September 2014 - Accepted: 30 September 2014 - Published: 1 December 2014

\begin{abstract}
Soils and other unconsolidated deposits in the northern circumpolar permafrost region store large amounts of soil organic carbon (SOC). This SOC is potentially vulnerable to remobilization following soil warming and permafrost thaw, but SOC stock estimates were poorly constrained and quantitative error estimates were lacking. This study presents revised estimates of permafrost SOC stocks, including quantitative uncertainty estimates, in the $0-3 \mathrm{~m}$ depth range in soils as well as for sediments deeper than $3 \mathrm{~m}$ in deltaic deposits of major rivers and in the Yedoma region of Siberia and Alaska. Revised estimates are based on significantly larger databases compared to previous studies. Despite this there is evidence of significant remaining regional data gaps. Estimates remain particularly poorly constrained
\end{abstract}

for soils in the High Arctic region and physiographic regions with thin sedimentary overburden (mountains, highlands and plateaus) as well as for deposits below $3 \mathrm{~m}$ depth in deltas and the Yedoma region. While some components of the revised SOC stocks are similar in magnitude to those previously reported for this region, there are substantial differences in other components, including the fraction of perennially frozen SOC. Upscaled based on regional soil maps, estimated permafrost region SOC stocks are $217 \pm 12$ and $472 \pm 27 \mathrm{Pg}$ for the $0-0.3$ and $0-1 \mathrm{~m}$ soil depths, respectively $( \pm 95 \%$ confidence intervals). Storage of SOC in $0-3 \mathrm{~m}$ of soils is estimated to $1035 \pm 150 \mathrm{Pg}$. Of this, $34 \pm 16 \mathrm{PgC}$ is stored in poorly developed soils of the High Arctic. Based on generalized calculations, storage of SOC below $3 \mathrm{~m}$ of surface 
soils in deltaic alluvium of major Arctic rivers is estimated as $91 \pm 52 \mathrm{Pg}$. In the Yedoma region, estimated SOC stocks below $3 \mathrm{~m}$ depth are $181 \pm 54 \mathrm{Pg}$, of which $74 \pm 20 \mathrm{Pg}$ is stored in intact Yedoma (late Pleistocene ice- and organic-rich silty sediments) with the remainder in refrozen thermokarst deposits. Total estimated SOC storage for the permafrost region is $\sim 1300 \mathrm{Pg}$ with an uncertainty range of $\sim 1100$ to $1500 \mathrm{Pg}$. Of this, $\sim 500 \mathrm{Pg}$ is in non-permafrost soils, seasonally thawed in the active layer or in deeper taliks, while $\sim 800 \mathrm{Pg}$ is perennially frozen. This represents a substantial $\sim 300$ Pg lowering of the estimated perennially frozen SOC stock compared to previous estimates.

\section{Introduction}

As permafrost warming and thaw occurs, large pools of soil organic carbon (SOC) that were previously protected by subzero temperatures may become available for mineralization, leading to increased greenhouse gas fluxes to the atmosphere (Schuur et al., 2008). Incorporating permafrost-related soil processes into Earth System Models (ESMs) has demonstrated that permafrost $\mathrm{C}$ and associated climate feedbacks have been underestimated in previous modelling studies and that high-latitude soil processes may further accelerate global warming (Koven et al., 2011; Schaefer et al., 2011; Burke et al., 2012a, b; Schneider von Deimling et al., 2012).

At high latitudes, low soil temperatures and poor soil drainage have reduced decomposition rates of soil organic matter (SOM) (Davidson and Janssens, 2006). Over millennial timescales, processes such as cryoturbation, accumulation of peat and repeated deposition and stabilization of organic-rich material (alluvium, proluvium, colluvium or wind-blown deposits) have led to accumulation of permafrost SOC in mineral soils, peat deposits (organic soils), silty late-Pleistocene syngenetic organic- and ice-rich deposits (Yedoma), deltaic deposits and other unconsolidated Quaternary deposits (e.g. Ping et al., 1998; Tarnocai and Stolbovoy, 2006; Schirrmeister et al., 2011a, b; Ping et al., 2011; Strauss et al., 2012). Using the Northern Circumpolar Soil Carbon Database (NCSCD), a digital soil map database linked to extensive field-based SOC storage data, Tarnocai et al. (2009) estimated the $0-0.3$ and $0-1 \mathrm{~m}$ SOC stocks in the northern circumpolar permafrost region to be 191 and $496 \mathrm{Pg}$, respectively. Based on limited field data, but in recognition of the key pedogenic processes that transport $\mathrm{C}$ to depth in permafrost soils, Tarnocai et al. (2009) provided a first-order SOC mass estimate for $0-3 \mathrm{~m}$ soil depth of $1024 \mathrm{Pg}$. This 0-3 m estimate was based on 46 pedons in Canada and was not included into the spatially distributed NCSCD. Hugelius et al. (2013a) recently compiled an updated pedon data set for soils in the northern circumpolar permafrost region extending down to 2 and $3 \mathrm{~m}$ depths ( $n=524$ and 356, respectively), which were incorporated into an updated NCSCDv2 which is now available to improve characterization of the 1-3 m SOC stocks.

A first-order estimate of SOC stocks in Yedoma terrain of $450 \mathrm{Pg}$ (Zimov et al., 2006) was calculated from a small-scale map of Yedoma extent (Romanovskii, 1993), using generalized data of Yedoma deposit thickness, massive ice content, organic $\mathrm{C} \%$ and bulk density. This estimate was recalculated to $407 \mathrm{Pg}$ to avoid double counting of SOC stocks in the top $3 \mathrm{~m}$ of deposits when included into a summative circumpolar estimate of Tarnocai et al. (2009). Schirrmeister et al. (2011a) suggested that Yedoma SOC stocks may be $25-50 \%$ lower than previously reported because of overestimated mean bulk density values in Yedoma deposits. Using newly compiled data on deposit thickness, spatial extent of thermokarst, bulk density, segregated ice content and massive wedge-ice content, Strauss et al. (2013) provide an updated estimate of $211 \mathrm{Pg}$ SOC (with an uncertainty range from 58 to $371 \mathrm{Pg}$ ) stored in permafrost sediments of the Yedoma region (including intact Yedoma and refrozen thermokarst sediment with Holocene cover deposits of Siberia and Alaska, not including active layer, thawed sediments underlying lakes and rivers or areas covered by deltaic or fluvial sediments).

Based on field data from the Mackenzie River delta, Tarnocai et al. (2009) estimated SOC storage in the deltaic deposits of seven selected Arctic river deltas to be $241 \mathrm{Pg}$. Since this first-order estimate demonstrated the potential importance of deltaic permafrost deposits, new knowledge has become available regarding deeper SOC stores in Arctic deltas. Field-studies from the Alaskan Beaufort Sea coast (Ping et al., 2011) and the Siberian Lena River delta (Schirrmeister et al., 2011b; Zubrzycki et al., 2013) provide new information on SOC stocks in near-surface deltaic deposits. There is also additional information regarding the spatial extent and depth of deltaic deposits (Walker, 1998; Aylsworth et al., 2000; S. L. Smith et al., 2005; Johnston and Brown, 1965; Taylor et al., 1996; Schwamborn et al., 2002).

Tarnocai et al. (2009) provided a total estimate of circumpolar SOC storage in soils (0-3 m depth), Yedoma and deltaic deposits of $1672 \mathrm{Pg}$, of which $1466 \mathrm{Pg}$ is stored in permafrost terrain. This is about twice as much $\mathrm{C}$ as what is currently stored in the atmosphere (Houghton, 2007). While it is recognized that this pool of SOC stored in permafrost regions is large and potentially vulnerable to remobilization following permafrost thaw, estimates are poorly constrained and quantitative error estimates are lacking (Mishra et al., 2013). Tarnocai et al. (2009) assigned qualitative levels of confidence for different components of the permafrost region SOC stock estimate. In recognition of the limited field observations on which estimates are based, estimates for SOC stocks stored in deep soil (1-3 m), Yedoma and deltaic deposits were assigned the lowest degree of confidence.

The aim of this paper is to update and synthesize the current state of knowledge on permafrost SOC stocks. We revise estimates of the permafrost SOC stocks for the $0-3 \mathrm{~m}$ depth range in soils as well as for deeper sediments in deltaic 
and Yedoma region deposits. Compared to previous studies (Tarnocai et al., 2009; Zimov et al., 2006), the number of individual field sites or pedons available for calculations has increased by a factor of 11 for $1-2 \mathrm{~m}$ soils, a factor of 8 for $2-3 \mathrm{~m}$ soils and deltaic alluvium and a factor of 5 for Yedoma region deposits. The first ever spatially distributed, quantified estimates for the $0-3 \mathrm{~m}$ depth range in soils are upscaled based on regional soil maps in the NCSCDv2. These estimates are calculated are calculated by separating physiographic regions of thick and thin sedimentary overburden, corresponding to lowland and highland areas, respectively (Heginbottom et al., 1993; Brown et al., 2002). In recognition of limited soil development in some high-latitude regions (Horwath Burnham and Sletten, 2010), SOC stocks in thin soils of the High Arctic bioclimatic zone are upscaled separately. A revised estimate of SOC stocks in deltaic deposits is based on new field data and updated information to calculate the spatial extent and depth of deltaic alluvium. For the Yedoma region, the estimate of Strauss et al. (2013) is recalculated by implementing an updated methodology for estimating uncertainty ranges and removing spatial overlap with SOC stored in surface soils. The different components of the permafrost region SOC stocks are summarized and presented together with quantitative uncertainty estimates. A primary goal of this study is to quantify uncertainties associated with permafrost SOC stocks estimates, and to improve understanding of the permafrost SOC pool size and distribution for model simulations of the permafrost-carbon feedback on the climate system.

\section{Methods}

Below we present a summary of methods used to obtain our estimates. More detailed descriptions of methods, including the data sets used for different calculations, are available in the online supplemental material.

\subsection{Calculating 0-3 m SOC stocks}

Calculation of SOC stocks (absolute amount of SOC reported as either $\mathrm{kg}$ or Pg SOC) based on thematic soil maps is done in three steps (Hugelius, 2012). First, the SOC storage (SOC amount per area unit, given in $\mathrm{kg} \mathrm{Cm}^{-2}$ ) for individual pedons (a pedon is a three-dimensional body of soil as sampled, described and classified in soil studies) is calculated to the selected reference depths. Second, the pedon data are grouped into suitable thematic upscaling classes, and mean SOC storage (with confidence intervals) for each class and reference depth is calculated. Finally, the mean SOC storage of each class is multiplied with estimates of the areal coverage of thematic upscaling classes to calculate total SOC stocks (including uncertainty ranges) for different classes and reference depths.
For this study, SOC stocks were estimated separately for the $0-0.3,0-1,1-2$ and $2-3 \mathrm{~m}$ depth ranges using the NCSCDv2. The NCSCDv2 is a polygon-based digital database adapted for use in Geographic Information Systems (GIS), which has been compiled from harmonized national or regional soil classification maps. Map data on soil coverage have been linked to pedon data with SOC storage from the northern permafrost regions to estimate geographically upscaled total SOC stocks (Hugelius et al., 2013b).

The SOC stocks estimates for the 0-0.3 and 0-1 m depth ranges were calculated separately in each NCSCDv2-region (i.e. Alaska, Canada, Contiguous USA, Europe, Greenland, Iceland, Kazakhstan, Mongolia, Russia and Svalbard) following the methodology of Tarnocai et al. (2009) but using the revised and gap-filled data sets described by Hugelius et al. (2013a, b). Separate SOC stock estimates were calculated for the High Arctic region. Outside the High Arctic, estimates of 1-3 m SOC stocks are based on a geographical subdivision following physiography. This spatial subdivision was chosen because it is expected to reflect different important pedogenic processes occurring across the studied region. Pedons and mapped soil areas in the northern circumpolar permafrost region were separated following physiographic regions of thick and thin sedimentary overburden (Fig. 1; see Heginbottom et al., 1993). Areas of thick sedimentary overburden are described as "areas of lowlands, highlands and intra- and inter-montane depressions characterised by thick overburden, wherein ground ice is expected to be generally fairly extensive" (Heginbottom et al., 1993). Areas of thin sedimentary overburden are described as "areas of mountains, highlands, and plateaus characterised by thin overburden and exposed bedrock, where generally lesser amounts of ground ice are expected to occur" (Heginbottom et al., 1993).

The upscaled SOC stock estimates for the $0-0.3$ and $0-1 \mathrm{~m}$ depth ranges were calculated separately for each soil order, following USDA Soil Taxonomy (Soil Survey Staff, 1999), within the separate NCSCDv2-regions. Permafrost-affected soils (Gelisol soil order) are further differentiated for upscaling into its three suborders: Turbels (cryoturbated permafrost soils), Histels (organic permafrost soils) and Orthels (noncryoturbated permafrost-affected mineral soils).

For the 1-2 and $2-3 \mathrm{~m}$ depth ranges, a reduced thematic resolution with aggregated upscaling classes was used. Stocks were calculated separately for the Turbel, Histel and Orthel suborders of the Gelisol soil order and for the Histosol soils order (organic soils without permafrost). All remaining soil orders were grouped as non-permafrost mineral soils.

The SOC storage $\left(\mathrm{kgCm}^{-2}\right)$ values for the $0-0.3$ and 0-1 $\mathrm{m}$ depth ranges were based on 1778 individual pedons from around the northern circumpolar permafrost region (mainly from Gelisol and Histosol orders), which have been complemented with SOC data from Batjes (1996) where data for non-permafrost soil orders was missing (this pedon data set is hereafter called pedon data set 1). More detailed information regarding this pedon data set, 


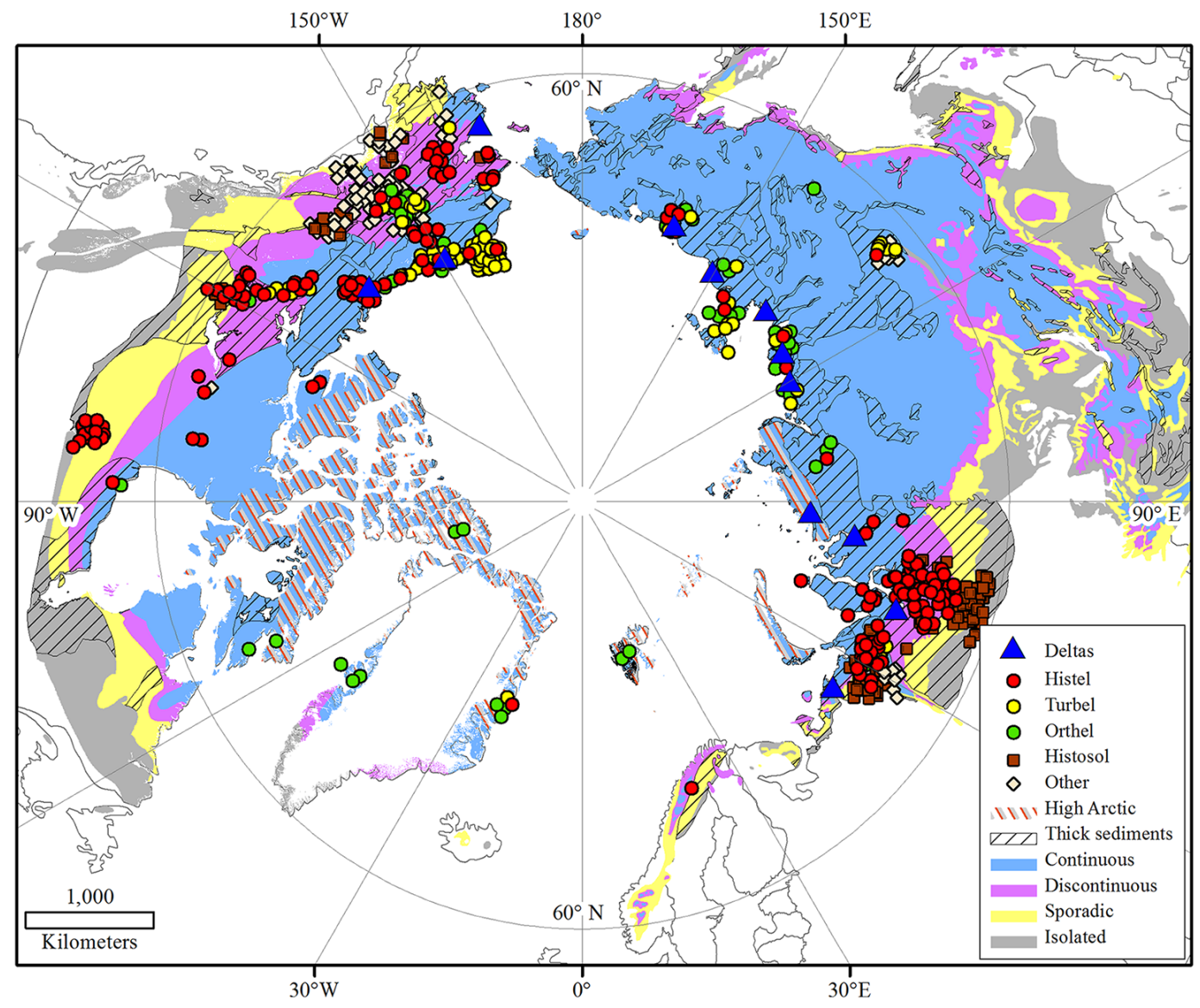

Figure 1. Geographical distribution of regions with thick sedimentary overburden and permafrost zonation in the northern circumpolar permafrost region (Brown et al., 2002). Map shows locations of the included Arctic river deltas as well as pedons with data in the 0-3 $\mathrm{m}$ depth range (pedon data set 2), grouped according to NCSCDv2 upscaling classes. Exact pedon locations have been manipulated for cartographic representation; projection: Azimuthal Equidistant, datum: WGS84. Adapted from Hugelius et al. (2013a).

includingdetailsregarding which soil orders were supplemented with information from Batjes (1996), can be found in the Supplementary Table S1 of the supplementary online materials. For further details regarding the NCSCD GIS database and the methods for pedon sampling and calculation of 0-0.3 and 0-1 m SOC stocks, see Hugelius et al. (2013b). For the deeper soil layers (1-2 and 2-3 m depth ranges) a newly compiled pedon database which has been integrated into the NCSCDv2 was used (Fig. 1; Table 1). From this pedon compilation we included 518 pedons that extend down to $2 \mathrm{~m}$ and 351 pedons that extend down to $3 \mathrm{~m}$ (this pedon data set is hereafter called pedon data set 2). Table 1 summarizes the number of individual deep pedons available from different geographical regions and areas of thick/thin sedimentary overburden in pedon data set 2 . More detailed information regarding this pedon data set can be found in Table $\mathrm{S} 1$ of the supplementary online materials.

\subsection{Calculating deltaic SOC stocks}

Deltaic SOC stocks in this study are estimated following the to a methodology that builds on that of Tarnocai et al. (2009) who used data on the mean depth of alluvium, mean delta lake coverage/depth and mean alluvium SOC density $\left(\mathrm{kg} \mathrm{Cm}^{-3}\right)$ from the Mackenzie River delta (Canada) combined with data on the spatial coverage of seven large Arctic river deltas. Here we combined the data used by Tarnocai et al. (2009) with updated information (from scientific literature and databases) on the areal extent of deltas, mean depth of alluvium, delta lake coverage, permafrost extent and segregated ice content in deltaic deposits. The total volume of alluvium for each delta was calculated from the mapped sub-aerial delta extents and the mean depth of alluvial deposits, subtracting the volume that was estimated to be occupied by massive ice and water bodies. To avoid double counting, the top $0-3 \mathrm{~m}$ of soil were removed from the calculation. In addition, known Yedoma deposits located in the Lena Delta were removed to avoid spatial overlap with 
Table 1. Summary of number of available pedons (with data below $1 \mathrm{~m}$ ) in areas with thick and thin sedimentary overburden for soil taxa from different regions (regional subdivision following NCSCD database structure) in the northern circumpolar region.

\begin{tabular}{|c|c|c|c|c|c|c|c|c|c|}
\hline \multirow{3}{*}{\multicolumn{2}{|c|}{$\begin{array}{l}\text { Soil order } \\
\text { Soil suborder }\end{array}$}} & \multicolumn{8}{|c|}{ Soil types ( $n$ of pedons at $1-2 \mathrm{~m} / 2-3 \mathrm{~m}$ depths) } \\
\hline & & \multicolumn{3}{|c|}{ Gelisols } & \multirow[t]{2}{*}{ Histosols } & \multirow[t]{2}{*}{ Alfisols } & \multirow[t]{2}{*}{ Entisols } & \multirow[t]{2}{*}{ Inceptisols } & \multirow[t]{2}{*}{ Spodosols } \\
\hline & & Histels & Turbels & Orthels & & & & & \\
\hline \multirow{7}{*}{ 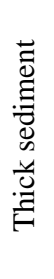 } & NCSCD region ${ }^{\mathrm{a}}$ & & & & & & & & \\
\hline & Alaska & $27 / 27$ & $52 / 8$ & $27 / 8$ & $1 / 1$ & - & $8 / 1$ & $37 / 8$ & $2 /-$ \\
\hline & Canada & $30 / 29$ & $4 / 3$ & $5 / 3$ & $6 / 6$ & $2 / 2$ & $3 / 1$ & $9 / 5$ & - \\
\hline & Greenland & - & - & - & - & - & - & - & - \\
\hline & Scandinavia/Svalbard & $1 / 1$ & - & $2 / 2$ & - & - & - & - & - \\
\hline & Russia & $89 / 89$ & $22 / 14$ & $27 / 21$ & $60 / 60$ & - & $1 / 1$ & $2 /-$ & $4 / 1$ \\
\hline & Thick sed. sum: & $147 / 146$ & $78 / 25$ & $61 / 34$ & $67 / 67$ & $2 / 2$ & $12 / 3$ & $48 / 13$ & $6 / 1$ \\
\hline \multirow{8}{*}{ 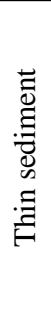 } & NCSCD region $^{a}$ & & & & & & & & \\
\hline & Alaska & $4 / 4$ & $1 /-$ & $2 /-$ & $5 / 5$ & - & $8 /-$ & $8 /-$ & $6 /-$ \\
\hline & Canada & $26 / 26$ & $3 / 2$ & $1 /-$ & $2 / 2$ & $3 / 3$ & - & $1 /-$ & - \\
\hline & Greenland & - & - & $3 /-$ & - & - & - & - & - \\
\hline & Scandinavia/Svalbard & - & - & - & - & - & - & - & - \\
\hline & Russia & $5 / 4$ & $2 /-$ & - & $1 / 1$ & - & $1 / 1$ & $7 / 7$ & - \\
\hline & High Arctic ${ }^{b}$ & $1 / 1$ & $1 / 1$ & $6 / 2$ & & & & & \\
\hline & Thin sed. sum: & $36 / 35$ & $7 / 3$ & $12 / 3$ & $8 / 8$ & $3 / 3$ & $9 / 1$ & $16 / 7$ & $6 /-$ \\
\hline \multicolumn{2}{|c|}{ Total sum: } & $183 / 181$ & $85 / 28$ & $73 / 37$ & $75 / 75$ & $5 / 5$ & $21 / 4$ & $64 / 20$ & $12 / 1$ \\
\hline
\end{tabular}

estimates for this region. When the total volume of alluvium was calculated, the total SOC stock of each delta was estimated using field data of mean alluvium SOC density $\left(\mathrm{kg} \mathrm{Cm}^{-3}\right)$. In all cases, mean values from other deltas were used when there was no direct data for any specific variable in a delta. Table 5 summarizes all input data used to estimate deltaic alluvium volume and SOC stocks. More detailed descriptions of calculations are available in the Supplement.

\subsection{Calculating permafrost SOC stocks in the Yedoma region}

For the purpose of these calculations, the Yedoma region was subdivided into areas of intact Yedoma deposits (late Pleistocene ice- and organic-rich silty sediments) and permafrost deposits formed in thaw-lake basins (generalized as thermokarst deposits) which may be either mineral soils, lake sediment or peat deposits. Volumes of unfrozen sediment underlying water bodies and areas covered by deltaic or fluvial sediments were excluded. Twenty-two Yedoma and ten thermokarst deposit profiles were studied and sampled from river or coastal bluffs exposed by rapid thaw and erosion (Strauss et al., 2013). Total SOC stocks in intact Yedoma and perennially frozen thermokarst deposits below $3 \mathrm{~m}$ are calculated based on individual observations of: deposit thickness ( $n=20$ and 8, respectively), organic $\mathrm{C}$ content (weight $\%, n=682$ and 219), bulk density $(n=428$ and 117), and wedge-ice content (volume $\%, n=10$ and 6). The upper $3 \mathrm{~m}$ of sediment were excluded to avoid spatial overlap with estimates of storage in $0-3 \mathrm{~m}$ soils based on the NCSCDv2. For details regarding calculations of the spatial extent of different sediments, data collection and spatial distribution of field observations see Strauss et al. (2013). Because of high inherent (spatial) heterogeneity and non-normal distributed input parameters, the SOC stock calculations are based on bootstrapping techniques using resampled observed values (similar to Strauss et al., 2013). The applied methodology differed from that of Strauss et al. (2013) in several ways. The number of resampling steps for each parameter was connected to the original number of observations of the different parameters deposit thickness, $\mathrm{C} \%$, bulk density, and wedge-ice. We did 10000 separate bootstrapping runs and the total mean SOC stock size estimate was derived afterward for every bootstrapping run. This resulted in an overall mean value calculated from 10000 observation-based bootstrapping means. Because organic $\mathrm{C} \%$ and bulk density of individual sediment samples are correlated, paired values were used in the resampling process. Computations were performed using $\mathrm{R}$ software (boot package) (R core team, 2012).

\subsection{Estimating SOC stock uncertainties}

Spatial upscaling using mean values of classes from thematic maps, such as soil maps, builds on the premise that 
an empirical connection between map classes and the investigated variable can be established through point sampling (Hugelius, 2012). Sources of upscaling uncertainty in such thematic mean upscaling can be divided into database uncertainty arising from insufficient field-data representation to describe natural soil variability within an upscaling class and spatial uncertainties caused by areal misrepresentation of classes in the upscaling map (Hugelius, 2012). Database uncertainty can be estimated based on the standard error (reflects variance and number of independent replicates) and the relative contribution towards the total stock of each upscaling class. This procedure assumes that the available sample is sufficiently replicated to accurately reflect the natural variability within a class. If this is not the case, the uncertainty arising from this so-called representation error can be estimated. Spatial errors in individual upscaling classes can be assessed if dedicated, comprehensive ground truth data sets to assess map accuracy are available, which is not the case in this study. All uncertainty estimates in this study assume that the spatial extent of different soil orders, deltas and the Yedoma region within the northern circumpolar permafrost region are correctly mapped.

Calculations of uncertainty ranges for the different depth ranges and regions of $0-3 \mathrm{~m}$ soil SOC stocks and deltaic alluvium are based on the methodology described by Hugelius (2012), modified to also include the estimated representation error in those cases where estimates for one region were based on small statistical samples. The uncertainty ranges are $95 \%$ confidence interval $(\mathrm{CI})$ ranges calculated from the standard deviation (SD) and proportional areal/volumetric contribution of each upscaling class. The relative contribution to total uncertainty by individual soil classes is defined as the proportion of combined SD and proportional areal/volumetric contribution of that class.

The uncertainty ranges for Yedoma region deposits are the 5 and 95th percentiles of bootstrapped observations (based on the methodology of Strauss et al., 2013). These ranges are considered equivalent to $95 \% \mathrm{CI}$ ranges. The uncertainty ranges of the different SOC stock components are combined using a formula for additive error propagation of covarying variables (Roddick, 1987). More detailed descriptions of all calculations, including formulas and a schematic overview of uncertainty calculations (Supplementary Fig. S1), are available in the Supplement.

\subsection{Statistical tests of significance}

Because different pedon data sets were used to calculate 0-1 m SOC stocks (pedon data set 1) and 1-3 m SOC stocks (pedon data set 2), there was a concern that these two data sets may not accurately reflect the same statistical populations (Hugelius, 2012). Therefore, the circumpolar mean $0-1 \mathrm{~m}$ SOC storage $\left(\mathrm{kg} \mathrm{Cm}^{-2}\right)$ between the two databases was compared using Student's $t$ test with $\alpha=0.05$ (test from parameters, software PAST v2.17b; Hammer et al., 2001).
These tests were performed at the reduced thematic resolution used to calculate deeper SOC stocks. Because the individual pedon observations and coordinates are no longer available for pedon data set 1 , the tests could not be done separately for the different physiographic regions (mean, standard deviation standard deviation and the number of individual observations in pedon data set 1 pedon data set 1 for the separate regions are not known).

For each soil upscaling class (at reduced thematic resolution), SOC storage $\left(\mathrm{kg} \mathrm{Cm}^{-2}\right)$ in the individual depth ranges $(0-1,1-2$ and $2-3 \mathrm{~m})$ were also compared across physiographic regions of thick and thin sedimentary overburden using a two-tailed Student's $t$ test with $\alpha=0.05$ (software PAST v2.17b).

\section{Results}

\subsection{Mean 0-3 m SOC storage and depth distribution in soil classes across regions}

\subsubsection{Mean pedon SOC storage used for upscaling}

Table 2 summarizes the SOC storage $\left(\mathrm{kg} \mathrm{C} \mathrm{m}^{-2}\right)$ and uncertainty ranges $(95 \% \mathrm{CI})$ for the different soil classes used in upscaling. More detailed information regarding the databases used to calculate mean SOC storage of different soil upscaling classes in all depth ranges can be found in Table S1 of the Supplement. In general, the highest mean SOC storages are in the organic soils (Histosols and Histels), followed by Turbels, Orthels and non-permafrost mineral soils. Organic soils and permafrost-affected soils also store more SOC below $1 \mathrm{~m}$ depth (except Orthels in regions of thin sediment overburden). Storage of SOC in poorly developed permafrost soils of the High Arctic is considerably lower than other permafrost soils. Estimates for soils of the High Arctic and physiographic regions of thin sedimentary overburden are associated with wide uncertainty ranges.

The mean SOC storage estimates used for upscaling (Table 2) are based on two different pedon data sets (pedon data set 1 above $1 \mathrm{~m}$ depth and data set 2 for deeper soils). However, both data sets have data for the top metre of soil. These two pedon data sets represent independent samples for estimating SOC storage $\left(\mathrm{kg} \mathrm{C} \mathrm{m}^{-2}\right)$ in the top metre of soils in the northern circumpolar permafrost region. If both data sets are assumed to be unbiased representative samples of SOC storage, they should provide similar estimates. Therefore, inter-comparisons of these estimates are informative. Comparing the $0-1 \mathrm{~m} \mathrm{SOC}$ storage $\left(\mathrm{kg} \mathrm{Cm}^{-2}\right)$ values from the two pedon data sets region revealed that there are no significant differences between the data sets for mean $0-1 \mathrm{~m}$ SOC storage (based on all circumpolar pedons) in the Orthel and Histel classes ( $t$ test, $p>0.05)$. Turbels and nonpermafrost mineral soils have significantly higher SOC in 
pedon data set $2(t$ test, $p<0.05)$. Histosols have significantly lower SOC in pedon data set $2(t$ test, $p<0.05)$.

\subsubsection{Comparison of SOC storage across regions and depths}

Pedon data set 1 has no data below $1 \mathrm{~m}$ depth and for consistency in comparisons only pedon data set 2 is referred to regarding all descriptions or comparisons of SOC storage across regions or depth distribution of SOC within soil classes. The vertical distribution of SOC through the profile varies greatly between soil orders (Fig. 2). In most soil classes the upper $1 \mathrm{~m}$ of soil stores more SOC than the deeper depth ranges but for Histosols, the highest estimated SOC storage is in the $1-2 \mathrm{~m}$ depth range (Fig. $2 \mathrm{~g}$ and $\mathrm{h}$ ). In Orthels in regions of thin sediment overburden, non-permafrost mineral soils and soils of the High Arctic, a large fraction (30-50\%) of total 0-3 m SOC is stored in the top-soil (upper $0.3 \mathrm{~m}$; Fig. 2e, i, j and k). Outside of the High Arctic, organic soils, Turbels and Orthels in thick sediment regions store $\sim 50 \%$ or more of SOC below $1 \mathrm{~m}$ depth.

Statistical comparison of SOC storage between physiographic regions of thick and thin sediment overburden shows significantly higher SOC in thick sediment regions across all depth ranges for Orthels and for non-permafrost mineral soils in 2-3 m depth (Fig. 2e, f, i and j; $t$ test, $p<0.05$ ). At depths down to $2 \mathrm{~m}$, Histosol SOC storage is significantly higher in thin sediment regions (Fig. $2 \mathrm{~g}$ and $\mathrm{h} ; t$ test, $p<0.05$ ). Other soil upscaling classes show no significant differences between physiographic regions.

\subsection{Upscaled soil area and SOC stocks across regions}

The estimated soil area of the northern circumpolar permafrost region is $17.8 \times 10^{6} \mathrm{~km}^{2}$ (excluding exposed bedrock, glaciers and ice-sheets and water bodies). This also includes the full areal extent of regions where permafrost coverage is non-continuous so that a significant fraction of the area is not in permafrost terrain. Physiographic regions with thick sedimentary overburden occupy $35 \%$ and regions with thin sedimentary overburden $65 \%$ of the soil area (Table 3). The North American continent (including Greenland) accounts for $39 \%$ of the soil area and Eurasia for $61 \%$ of the soil area.

Total estimated northern circumpolar permafrost region SOC stocks ( $\pm 95 \% \mathrm{CI})$ are $217 \pm 12 \mathrm{Pg}$ for the $0-0.3 \mathrm{~m}$ depth and $472 \pm 27 \mathrm{Pg}$ for the $0-1 \mathrm{~m}$ depth (Table 3 ). Estimated deeper SOC stocks are $355 \pm 81 \mathrm{Pg}$ for the $1-2 \mathrm{~m}$ depth and $207 \pm 42 \mathrm{Pg}$ for the $2-3 \mathrm{~m}$ depth (Table 2). The summarized SOC stocks for $0-2 \mathrm{~m}$ depth are $827 \pm 108 \mathrm{Pg}$ and for $0-3 \mathrm{~m}$ depth are $1035 \pm 150 \mathrm{Pg}$.

Thick sediment areas have lower total SOC stocks than thin sediment areas in the $0-0.3,0-1$ and $1-2 \mathrm{~m}$ depth ranges (corresponding to a significantly smaller areal coverage). However, in the 2-3 m depth range the total SOC stocks are higher in areas of thick sediments, reflecting the very low estimated SOC contents below $2 \mathrm{~m}$ depth for some soil classes which have significant areal extent in thin sediment regions (i.e. Orthels and non-permafrost mineral soils; Fig. 2 and Table S1). There is a clear trend of wider uncertainty ranges in thin sediment regions, caused by variable mean SOC storage (Fig. 2) and a low number of available pedons for this very large region (Table 1). Maps of estimated SOC content (Fig. 3) show clear differences in estimated SOC stocks, with higher numbers in thick sediment regions than in the thin sediment regions.

The High Arctic region occupies $6 \%$ of the northern circumpolar permafrost region and stores an estimated $34 \pm$ $16 \mathrm{Pg} \mathrm{SOC}$ in the $0-3 \mathrm{~m}$ depth range (3\% of total permafrost region 0-3 $\mathrm{m}$ SOC stocks). Most of this is in the upper metre of the soil with $10 \pm 3$ and $24 \pm 8$ Pg SOC in the $0-0.3$ and $0-1 \mathrm{~m}$ depth ranges, respectively. Estimates of SOC stocks in deeper soil layers in the High Arctic are lower, $7 \pm 5$ and $3 \pm 3 \mathrm{Pg}$ SOC in the 1-2 and 2-3 m depth ranges, respectively.

Permafrost-affected soils dominate SOC storage in the permafrost region with $70 \%$ of total stocks (Table 4). Turbels outside of the High Arctic region, which account for $31 \%$ of the soil area, store $41 \%$ of total 0-3 m SOC stocks (Table 4), and is the single dominant upscaling class across all depth ranges and regions (Table $\mathrm{S} 1$ ). In the $1-2 \mathrm{~m}$ depth range, the organic soils (Histels and Histosols) contribute more to the total SOC stocks, due to higher mean SOC storage in that depth interval (Fig. 2). Histosols are especially important in regions of thick sedimentary overburden where the mean depth of peat deposits (data not shown) and mean SOC stocks are greater. Outside of continuous permafrost covergae, non-permafrost mineral soils cover $38 \%$ of the northern circumpolar permafrost region, but accounts for only $15 \%$ of the SOC mass.

Estimates for permafrost soils are the most uncertain. For the 0-1 m SOC stock estimate, Turbels, Orthels and Histels together account for $89 \%$ of the total estimated uncertainty (61, 14 and $15 \%$ respectively). At greater depths, uncertainties increase further. Overall, the Turbels introduces the most uncertainty to the SOC stock estimates across depth ranges, especially at depths below $1 \mathrm{~m}$. Turbels account for $54-89 \%$ and $72-90 \%$ of upscaling uncertainty (1-2 and $2-3 \mathrm{~m}$ depth ranges, respectively). The particularly large uncertainties of Turbel SOC storage estimates in physiographic regions of thin sedimentary overburden are caused by few available pedons that show large within-class variability. The relative uncertainties of High Arctic soil SOC stocks are large. However, these soils have low SOC stocks $(0.2-4 \%$ of total permafrost region SOC stocks across depth ranges) and contribute little towards the uncertainty of the total estimates. More detailed information regarding the total soil area, SOC stocks and relative contribution towards the estimated uncertainty ranges of different soil upscaling classes in all depth ranges can be found in Table S1 of the online supplementary materials. 

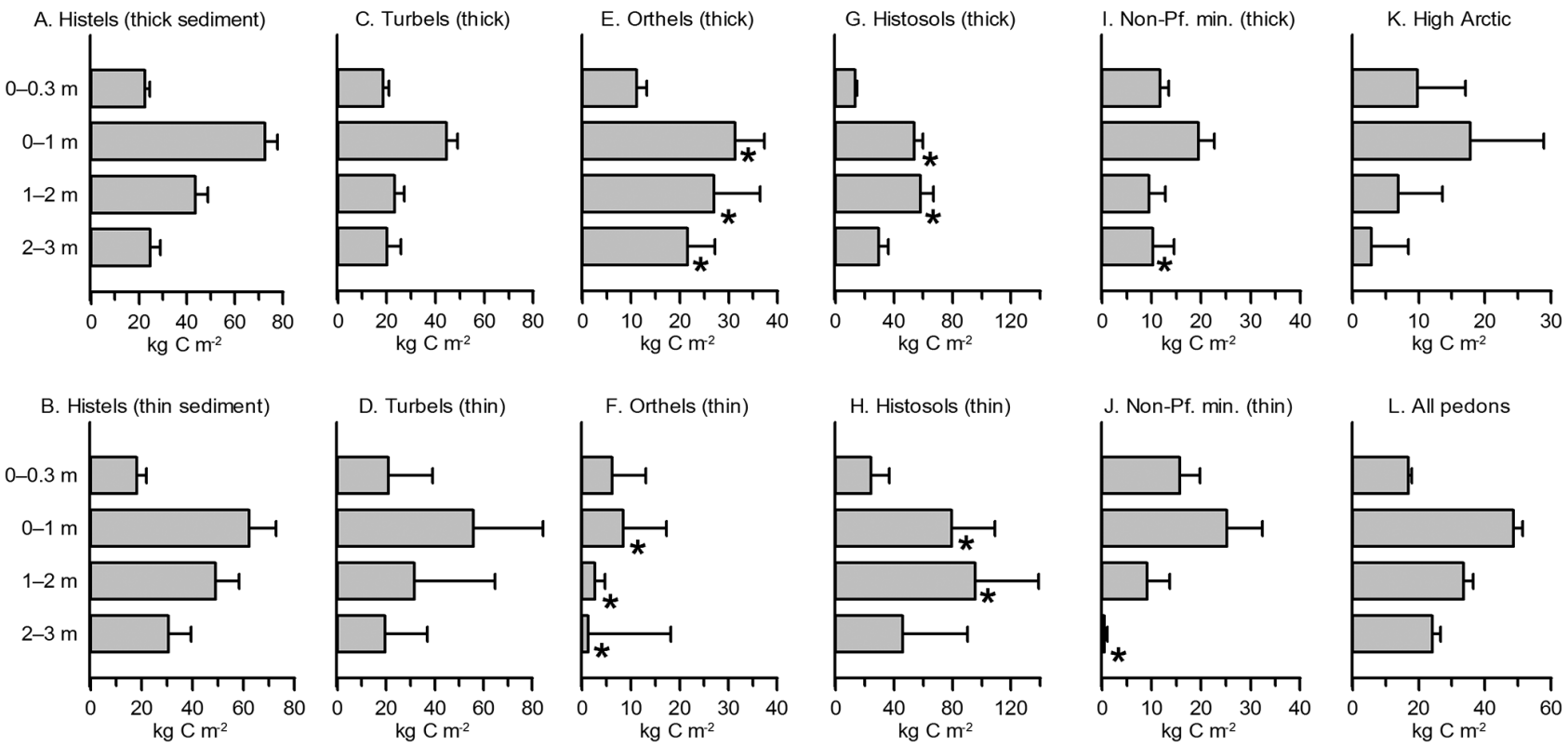

Figure 2. Mean SOC storage $\left(\mathrm{kg} \mathrm{Cm}^{-2}\right)$ with error bars showing $95 \%$ confidence intervals of the mean, for different soil upscaling classes calculated using pedon data set 2. Panels (a) to (j) show SOC storage estimates for the different depth ranges in areas of thick and thin sedimentary overburden, respectively. Panels (k) and (j) show mean SOC storage for the High Arctic region and for all pedons grouped together. Asterisks mark depth intervals in soil upscaling classes where SOC storage is significantly different from the equivalent interval in the other region $(t$ test, $p<0.05)$.

Table 2. Summary of mean SOC storage in different depth ranges of the soil upscaling classes for the upscaling regions applied in this study. Numbers for soils above $1 \mathrm{~m}$ depth are based on pedon data set 1 while numbers for soils from 1-3 m depth are based on pedon data set 2 . Note that for soils below $1 \mathrm{~m}$ depth all non-permafrost mineral soils (non-pf. min.) are combined in one upscaling class. Per our definition of High Arctic soils, these soils are not found in physiographic regions with thick sedimentary overburden.

\begin{tabular}{|c|c|c|c|c|c|c|}
\hline \multirow{3}{*}{$\begin{array}{l}\text { Region: } \\
\text { Depth range: } \\
\text { Soil class: }\end{array}$} & \multicolumn{2}{|c|}{ Circumpolar } & \multicolumn{2}{|c|}{ Thick sediment } & \multicolumn{2}{|c|}{ Thin sediment } \\
\hline & $0-0.3 \mathrm{~m}$ & $0-1 \mathrm{~m}$ & $1-2 \mathrm{~m}$ & $2-3 \mathrm{~m}$ & $1-2 \mathrm{~m}$ & $2-3 \mathrm{~m}$ \\
\hline & \multicolumn{6}{|c|}{ SOC storage $\pm 95 \% \mathrm{CI}\left(\mathrm{kgC} \mathrm{m}^{-2}\right)$} \\
\hline Alfisols & $4.7 \pm 0.4$ & $7.9 \pm 0.7$ & & & & \\
\hline Entisols & $1.1 \pm 0.8$ & $7.7 \pm 1.7$ & & & & \\
\hline Inceptisols & $4.9 \pm 0.2$ & $9.5 \pm 0.4$ & & & & \\
\hline Spodosols & $11.7 \pm 2$ & $21.3 \pm 5$ & & & & \\
\hline Natric soils & $2.9 \pm 0.6$ & $10.6 \pm 2.2$ & & & & \\
\hline Aquic soils & $9.2 \pm 0.4$ & $16.8 \pm 0.7$ & & & & \\
\hline Vertisols & $5.7 \pm 2.1$ & $13.5 \pm 4.9$ & & & & \\
\hline Mollisols & $6.4 \pm 0.4$ & $12.2 \pm 0.7$ & & & & \\
\hline Aridisols & $1.6 \pm 1.8$ & $1.7 \pm 5.4$ & & & & \\
\hline Andisols & $11.4 \pm 0.4$ & $25.4 \pm 0.2$ & & & & \\
\hline Ultisols & $5.1 \pm 1.2$ & $9.4 \pm 3.2$ & & & & \\
\hline Non-pf. min. & & & $9.5 \pm 3.3$ & $10.3 \pm 3.3$ & $9.1 \pm 4.6$ & $0.5 \pm 0.6$ \\
\hline Histosols & $22.5 \pm 0.5$ & $69.1 \pm 0.9$ & $58 \pm 9$ & $29.8 \pm 9$ & $95.7 \pm 43.4$ & $46.1 \pm 44.2$ \\
\hline Turbels & $14.7 \pm 1.5$ & $33 \pm 3.5$ & $23.2 \pm 4.1$ & $20.1 \pm 4.1$ & $31.6 \pm 33.1$ & $19.5 \pm 17.5$ \\
\hline Orthels & $15.8 \pm 2.6$ & $25.3 \pm 4.1$ & $27 \pm 9.5$ & $21.6 \pm 9.5$ & $2.6 \pm 2$ & $1.3 \pm 16.9$ \\
\hline Histels & $18.1 \pm 3$ & $49.3 \pm 8.4$ & $43.6 \pm 5.1$ & $24.8 \pm 5.1$ & $49 \pm 9.2$ & $30.5 \pm 8.8$ \\
\hline High Arctic & $9.8 \pm 7.4$ & $17.8 \pm 11$ & & & $6.9 \pm 6.7$ & $2.8 \pm 5.6$ \\
\hline
\end{tabular}




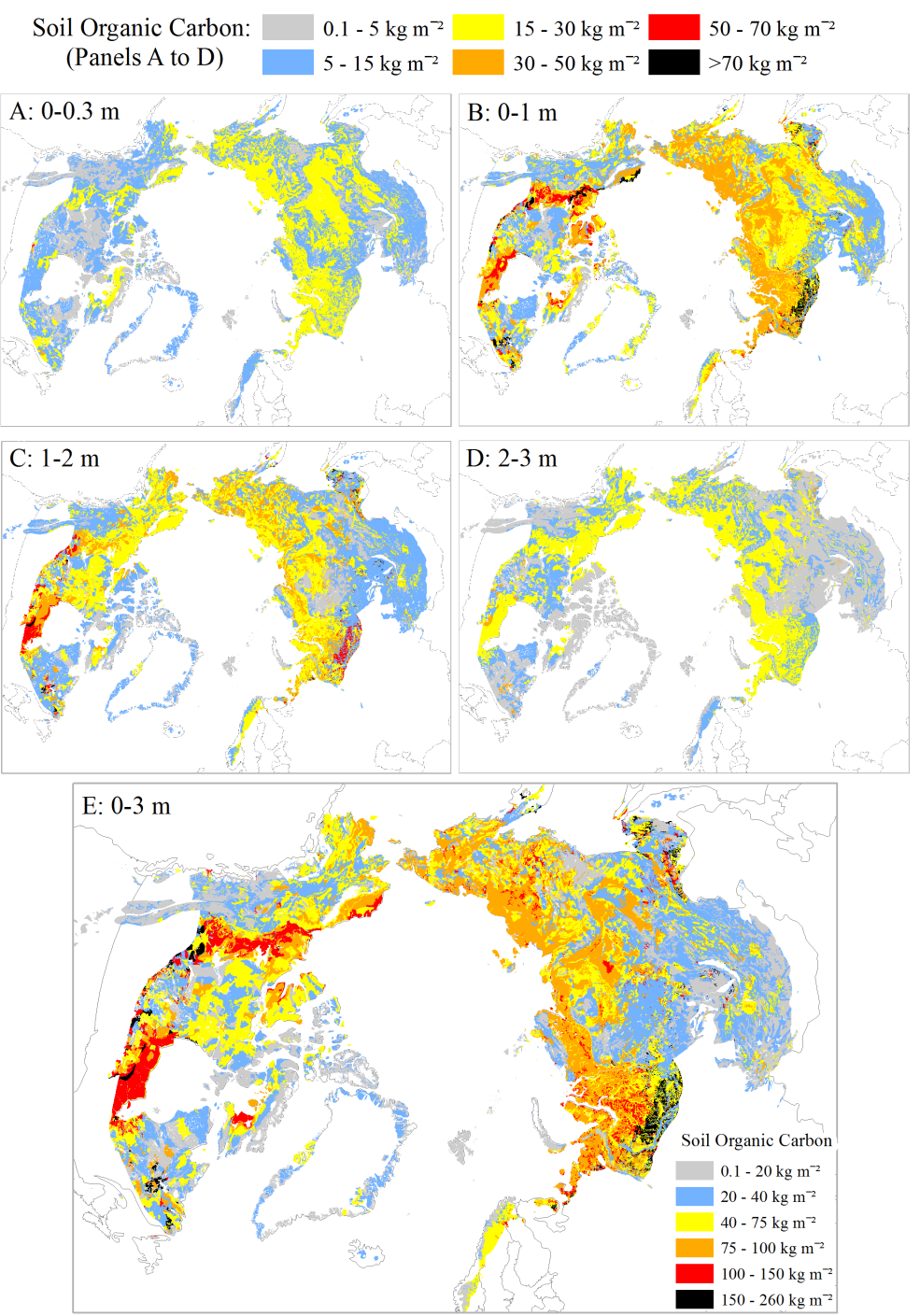

Figure 3. Map of estimated 0-3 $\mathrm{m} \mathrm{SOC}$ storage $\left(\mathrm{kg} \mathrm{Cm}^{-2}\right)$ in the northern circumpolar permafrost region. Panels show $0-0.3 \mathrm{~m}$ and $0-1 \mathrm{~m}$ SOC calculated subdivided following NCSCD regions while 1-2 $\mathrm{m}$ and 2-3 $\mathrm{m}$ SOC is calculated subdivided for areas of thick thin sedimentary overburden. Projection: Azimuthal Equidistant, datum: WGS84.

Table 3. Summary of estimated soil area and SOC stocks (with $\pm 95 \%$ CI where available) subdivided into physiographic regions of thick and thin sedimentary overburden (following Brown et al., 2002), the High Arctic region and summarized for the northern circumpolar permafrost region.

\begin{tabular}{lcccc}
\hline & Thick sediments & Thin sediments & High Arctic region \\
Soil area $\left(\mathrm{km}^{2}\right):$ & $6.2 \times 10^{6}(35 \%)$ & $\begin{array}{c}\text { Circumpolar } \\
10.6 \times 10^{6}(59 \%)\end{array}$ & $1.0 \times 10^{6}(6 \%)$ & $17.8 \times 10^{6}$ \\
\hline SOC stocks $(\mathrm{Pg}):$ & & & & \\
$0-0.3 \mathrm{~m}$ & 90 & 117 & $10 \pm 3$ & $217 \pm 12$ \\
$0-1 \mathrm{~m}$ & 213 & 235 & $24 \pm 8$ & $472 \pm 27$ \\
$1-2 \mathrm{~m}$ & $161 \pm 14$ & $187 \pm 79$ & $7 \pm 5$ & $355 \pm 81$ \\
$2-3 \mathrm{~m}$ & $119 \pm 16$ & $86 \pm 39$ & $3 \pm 3$ & $207 \pm 42$ \\
$0-2 \mathrm{~m}$ & 374 & 422 & $31 \pm 13$ & $827 \pm 108$ \\
$0-3 \mathrm{~m}$ & 493 & 507 & $34 \pm 16$ & $1035 \pm 150$ \\
\hline
\end{tabular}


Table 4. Summary of areal coverage ( $\%$ of total permafrost region coverage) and total estimated SOC stocks (with \% of total) of soil upscaling classes with reduced thematic resolution.

\begin{tabular}{|c|c|c|}
\hline Soil classes & $\begin{array}{l}\text { Area } \\
\mathrm{km}^{2}\end{array}$ & $\begin{array}{c}\text { SOC stocks } \\
\text { in } 0-3 \mathrm{~m} \\
\mathrm{Pg}\end{array}$ \\
\hline Turbels ${ }^{\mathrm{a}}$ & $5.5(31 \%)$ & $454(44 \%)$ \\
\hline Orthels ${ }^{\mathrm{a}}$ & $2.3(13 \%)$ & $92(9 \%)$ \\
\hline Histels $^{\mathrm{a}}$ & $1.2(7 \%)$ & $147(14 \%)$ \\
\hline High Arctic soils ${ }^{b}$ & $1.1(6 \%)$ & $34(3 \%)$ \\
\hline High Arctic Turbels & $0.7(4 \%)$ & $22(2 \%)$ \\
\hline High Arctic Orthels & $0.2(1 \%)$ & $6(0.6 \%)$ \\
\hline High Arctic Histels & $0.2(1 \%)$ & $6(0.6 \%)$ \\
\hline Gelisols sum: ${ }^{c}$ & $10.1(57 \%)$ & $727(70 \%)$ \\
\hline Histosols & $0.9(5 \%)$ & $149(14 \%)$ \\
\hline Non-Gelisols, mineral & $6.8(38 \%)$ & $158(15 \%)$ \\
\hline Total & $17.8 \times 10^{6} \mathrm{~km}^{2}$ & $1035 \mathrm{Pg}$ \\
\hline
\end{tabular}

\footnotetext{
a Applies to Gelisol suborders outside of the High Arctic region.

b A very small fraction $(<1 \%)$ of the High Arctic is mapped as

non-Gelisols but these soils are equally subdivided to Gelisol suborders here.

${ }^{c}$ Note that this class is not used in upscaling and is included here for

summative purposes only.
}

\subsection{SOC stocks below $3 \mathrm{~m}$ depth in deltaic deposits}

Table 5 summarizes data sources, the different parameters used to estimate the volume and SOC content of deltaic alluvium and calculated results for the individual deltas. The total estimated area of major river deltas in the northern circumpolar permafrost region is $75800 \mathrm{~km}^{2}$. This estimate includes 12 deltas ranging in size from 500 to $32000 \mathrm{~km}^{2}$. The combined estimated alluvium volume below $3 \mathrm{~m}$ depth in these deltas is ca. $3500 \mathrm{~km}^{3}$ (stored between 3 and $60 \mathrm{~m}$ depth, mean alluvium depth is $54 \mathrm{~m}$ ). Field-based observations of alluvium depth are very limited and estimates are based on only one observation for the Lena River delta and five different observations for the Mackenzie River delta. Estimates for mean alluvium SOC density are available from the literature for five different delta units and range from 8.3 to $56.2 \mathrm{~kg} \mathrm{C} \mathrm{m}^{-3}$. For deltas where no direct observations are available, alluvium depth and SOC content is estimated from the mean values of those deltas that have data.

Estimated SOC stocks in deltaic alluvium below $3 \mathrm{~m}$ depth are $91 \pm 52 \mathrm{Pg}$. Because of high mean alluvium SOC density total stocks in the Mackenzie River delta (34 Pg) are higher than those of the Lena River delta ( $23 \mathrm{Pg})$, which is considerably larger and accounts for $44 \%$ of the total estimated volume of alluvium. The Yana River delta stores an estimated $7 \mathrm{Pg}$ and alluvial deposits of the remaining nine deltas store the remaining $27 \mathrm{Pg}(\leq 5 \mathrm{Pg}$ each). Between 51 and $92 \%$ (mean $84 \%$ ) of deltaic alluvium is stored in permafrost. Estimated SOC stocks in perennially frozen alluvium are $69 \pm 38 \mathrm{Pg}$. For most of the deltas included in this estimate, no field-observations of alluvium depth or SOC content are available. Calculated CI intervals indicate that uncertainties arising from limited observations of alluvium depth $( \pm 49 \mathrm{Pg})$ are greater than uncertainties from poorly estimated alluvium SOC density $( \pm 18 \mathrm{Pg})$.

\subsection{Storage of permafrost SOC in the Yedoma region}

The combined area of the Yedoma core region in Siberia (Romanovskii, 1993) and Alaska (Jorgenson et al., 2008) is $1387000 \mathrm{~km}^{2}$. Of this $416000 \mathrm{~km}^{2}(30 \%)$ is considered intact Yedoma and $775000 \mathrm{~km}^{2}(56 \%)$ is comprised of permafrost deposits that have previously gone through thermokarst cycling (refrozen sediments accumulated in thaw-lake basins, including mineral soil, lake sediment or peat deposits) (Grosse et al., 2013; Strauss et al., 2013). Within this Yedoma core region, thawed sediments underlying lakes and rivers $\left(150000 \mathrm{~km}^{2}\right)$ and areas covered by deltaic or fluvial sediments $\left(47000 \mathrm{~km}^{2}\right)$ are excluded from calculations.

The estimated stocks of permafrost SOC below $3 \mathrm{~m}$ depth in the Yedoma region is $181 \mathrm{Pg}$ with an uncertainty range of $130-239 \mathrm{Pg}$ (hereafter approximated to $\pm 54 \mathrm{Pg}$ ). Of this an estimated $74 \mathrm{Pg}$ with an uncertainty range of 55-94 Pg (hereafter approximated to $\pm 20 \mathrm{Pg}$ ) is stored in intact Yedoma while 107 with an uncertainty range of $60-161 \mathrm{Pg}$ (hereafter approximated to $\pm 50 \mathrm{Pg}$ ) is stored in perennially frozen thermokarst basin deposits.

The estimated total stocks of permafrost SOC in the Yedoma region is $213 \mathrm{Pg}$ with an uncertainty range of $164-267 \mathrm{Pg}$ (hereafter approximated to $\pm 52 \mathrm{Pg}$ ). Of this an estimated $83 \mathrm{Pg}$ with an uncertainty range of $64-104 \mathrm{Pg}$ (hereafter approximated to $\pm 20 \mathrm{Pg}$ ) is stored in intact Yedoma while $130 \mathrm{Pg}$ with an uncertainty range of $85-180 \mathrm{Pg}$ (hereafter approximated to $\pm 45 \mathrm{Pg}$ ) is stored in perennially frozen thermokarst basin deposits.

\section{Discussion}

This study presents updated estimates of SOC stocks in the northern circumpolar permafrost region based on markedly improved databases. The study includes the first spatially distributed quantification of $1-3 \mathrm{~m}$ SOC stocks as well as the first quantitative uncertainty ranges for SOC stocks in this region. In recognition of the limited soil development in high-latitude areas with thin sediments, the High Arctic region was treated separately in upscaling. Adding up SOC stocks in $0-3 \mathrm{~m}$ soils, deltaic deposits and Yedoma region permafrost deposits for the northern circumpolar permafrost region results in an estimate of $1307 \mathrm{Pg}$ with an uncertainty range of $1140-1476 \mathrm{Pg}$ (roughly $\pm 170 \mathrm{Pg}$ ). Of this, $999 \mathrm{Pg}$ of SOC is stored in permafrost terrain (defined as storage in Gelisols/High Arctic soils and in deposits below $3 \mathrm{~m}$ depth). The SOC stock in perennially frozen soil and sediment is estimated to be $822 \mathrm{Pg}$ (or $63 \%$ ) or less (assuming an active 


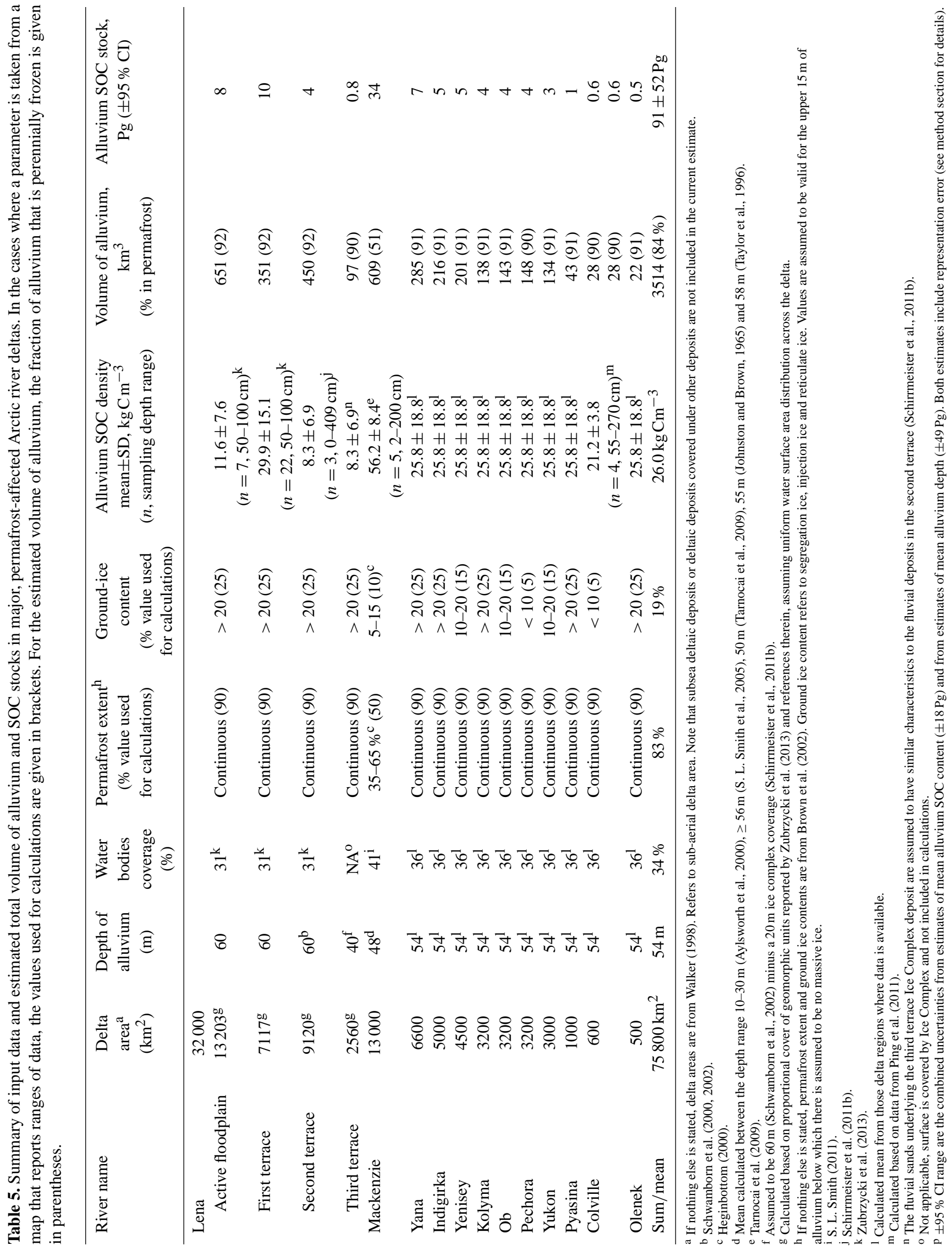


Table 6. Summative comparison of permafrost SOC stocks between the previous estimates in Tarnocai et al. (2009) and this study.

\begin{tabular}{|c|c|c|c|}
\hline Soil organic carbon stocks & $\begin{array}{l}\text { Tarnocai et al. (2009) } \\
\text { Pg (\% of region total) }\end{array}$ & $\begin{array}{c}\text { This study } \\
\text { Pg (\% of region total })\end{array}$ & $\begin{array}{l}\text { Difference } \\
\quad \text { Pg }\end{array}$ \\
\hline \multicolumn{4}{|l|}{ Soils in the $0-3 \mathrm{~m}$ depth range } \\
\hline Turbels & $581(35 \%)$ & $476(36 \%)$ & -105 \\
\hline Orthels & $53(3 \%)$ & $98(7 \%)$ & +45 \\
\hline Histels & $184(11 \%)$ & $153(12 \%)$ & -31 \\
\hline Sub-total Gelisols & $818(49 \%)$ & $727(56 \%)$ & -91 \\
\hline Gelisols in permafrost $^{\mathrm{a}}$ & $692(41 \%)$ & $572(44 \%)$ & -120 \\
\hline Histosols & $94(6 \%)$ & $149(11 \%)$ & +55 \\
\hline Non-Gelisols, mineral & $112(7 \%)$ & $158(12 \%)$ & +46 \\
\hline Total for $0-3 \mathrm{~m}$ soils & $1024(61 \%)$ & $1035(79 \%)$ & +11 \\
\hline \multicolumn{4}{|l|}{ Deposits below $3 \mathrm{~m}$ depth } \\
\hline Deltaic alluvium & $241(14 \%)$ & $91(7 \%)$ & -150 \\
\hline Yedoma region & $407(24 \%)$ & $181(14 \%)$ & -226 \\
\hline \multicolumn{4}{|c|}{ Combined SOC in soils $(0-3 \mathrm{~m})$, deltaic alluvium and Yedoma region sediments } \\
\hline In permafrost terrain ${ }^{b}$ & $1466(88 \%)$ & $977(75 \%)$ & -489 \\
\hline In permafrost ${ }^{\mathrm{a}}$ & $1134(68 \%)$ & $822(63 \%)$ & -312 \\
\hline Total permafrost region & 1672 & 1307 & -365 \\
\hline
\end{tabular}

layer depth of $30 \mathrm{~cm}$ or more in all Gelisols and High Arctic soils).

\subsection{Differences to previous estimates}

The methodological approach of this estimate is similar to that taken by Tarnocai et al. (2009) who provided a previous depth-integrated estimate of permafrost region SOC stocks. Revised databases and methodology lead to substantial reductions of estimated total SOC stocks (Table 6), especially below $3 \mathrm{~m}$ depth. There is a considerable reduction in estimates of SOC stored in permafrost terrain and in permafrost.

The updated estimates of northern circumpolar permafrost region SOC stocks in $0-0.3$ and $0-1 \mathrm{~m}$ depth are largely based on the same data as the equivalent estimates of Tarnocai et al. (2009). Differences between estimates $(+26$ and $-24 \mathrm{Pg}$, respectively) are due to gap-filling procedures and updating of the NCSCD spatial framework (see Hugelius et al., 2013a,b) and to new SOC estimates for the High Arctic region. The updated pedon database used to estimate SOC between 1 and $3 \mathrm{~m}$ depth includes spatial representation across the northern circumpolar permafrost region and about a tenfold increase in the number of pedons compared to that of Tarnocai et al. (2009). While the relative changes in the total 0-3 m SOC stocks are small, there are considerable differences between individual soil orders. The revised estimates are considerably lower for Turbels and Histels but higher for Orthels, Histosols and non-permafrost mineral soils (Table 6). This results in a $120 \mathrm{Pg}$ reduction of SOC stored in permafrost in the $0-3 \mathrm{~m}$ depth range compared to the previous estimate. Note that the estimates of the fraction of SOC stored in permafrost are highly uncertain as they are based on an assumption that the average active layer depth in all Gelisols is $0.3 \mathrm{~m}$ or more (see Kuhry et al., 2013).

Using a subset of pedon data set 2 and soil (sub)order coverage from the NCSCD, Harden et al. (2012) estimated total northern Gelisol SOC stocks to be $1060 \mathrm{Pg}$, compared to $727 \mathrm{Pg}$ in this estimate. The major cause for this difference is that Harden et al. (2012) did not subdivide the upscaling following physiographic regions, which leads to higher estimated mean SOC storage in Gelisol soil orders for regions of thin sedimentary overburden.

In recognition of the limited soil development in highlatitude areas with thin sediments, the High Arctic region was treated separately in upscaling. A previous study estimated active layer SOC stocks for this region to be $12 \mathrm{Pg}$ (Horwath Burnham and Sletten, 2010), which falls within current SOC estimates of $10 \pm 3$ and $24 \pm 8 \mathrm{Pg}$ in the $0-0.3$ and $0-1 \mathrm{~m}$ depth ranges, respectively.

The previous estimate of deltaic SOC stocks by Tarnocai et al. (2009) was extrapolated based on field data from the Mackenzie River delta only. The revised, substantially lower, estimate presented here builds on this same basic methodology but with some additional sources of data from the literature. The difference between estimates is mainly caused by lower estimates of mean alluvium SOC density $\left(\mathrm{kg} \mathrm{C} \mathrm{m}^{-3}\right)$ when including new data from the Colville and Lena river deltas (Ping et al., 2011; Schirrmeister et 
al., 2011b; Zubrzycki et al., 2013). There are smaller differences in the estimated total volume of deltaic alluvium. This is calculated based on areal extent and depth of alluvium, accounting for the volume of water bodies (assuming a mean water depth of $5 \mathrm{~m}$ ) and volumetric massive ice content. While the areal extent of deltas for the updated estimate is based on an entirely different source (Walker, 1998) and includes a larger subset of individual deltas, the difference in total estimated sub-aerial delta surfaces is relatively small. The estimated depth of alluvium in deltas is also similar to the original estimate. Tarnocai et al. (2009) consider all deltaic alluvium below $3 \mathrm{~m}$ to be in permafrost and do not consider any reduced alluvium volume caused by occurrences of massive ice. If no massive ice content is assumed in this study, the equivalent estimate would increase from $91 \pm 52$ to $98 \pm 54 \mathrm{Pg}$.

The updated estimate of permafrost SOC storage below $3 \mathrm{~m}$ depth in the Yedoma region is based on the same data set as the estimate for the total permafrost SOC stocks in this region developed by Strauss et al. (2013). Removing depth overlap with the $0-3 \mathrm{~m}$ soil estimate resulted in a reduction from 213 to $181 \mathrm{Pg}$. The substantial reduction compared to the previous depth-integrated estimate by Tarnocai et al. (2009) is mainly caused by a twofold reduction of estimated bulk density, a reduction of estimated deposit thickness, and different assumptions regarding the characteristics of intact Yedoma compared to refrozen thermokarst sediments (see Fig. 3 in Strauss et al., 2013).

\subsection{Distribution patterns of $\mathrm{SOC}$ stored in $0-3 \mathrm{~m}$ soil}

\subsubsection{SOC distribution by regions}

When compiling pedon data set 2 for upscaling of SOC stocks in the 1-3 m depth range Hugelius et al. (2013a) subdivided pedons and upscaled SOC stocks based on a continental subdivision (North America vs. Eurasia) as opposed to the upscaling based on physiographic regions used in this study. A first version of this study included both continental and physiographic upscaling (Hugelius et al., 2014). This study is based only on physiographic upscaling as we argue that this approach reflects a more accurate assessment of SOC distribution than subdivision by continent. The physiographic regions reflect differences between upland and lowland areas across the northern circumpolar permafrost region (Heginbottom et al., 1993) and are better suited to reflect different soil types and important pedogenic processes. This is also consistent with other studies that have utilized physiography and its influence on soil drainage to upscale soil properties (Harden et al., 2003; Yi et al., 2009). A map of mean SOC storage (Fig. 3) upscaled using physiography shows important patterns that were lacking in continent-based upscaling (Hugelius et al., 2014). For example, in the 1-2 m depth range, mountainous regions in Siberia emerge as having low SOC stocks below $1 \mathrm{~m}$. This estimate upscaled based on physiographic regions reflects differences between upland and lowland areas across the northern circumpolar permafrost region (Heginbottom et al., 1993). In thin sediment areas ("areas of mountains, highlands, and plateaus characterised by thin overburden and exposed bedrock") we would generally expect conditions to be less favourable for accumulation of large SOC stocks than in areas of thick sediment overburden ("areas of lowlands, highlands and intraand inter-montane depressions characterised by thick overburden"). The overall upscaled SOC stock estimates follows this pattern of higher stocks in thick sediment areas, but some individual soils classes do not. Our estimates for thin sediment areas are characterized by large variability, poor pedon representation, and wide uncertainty ranges (see Sect. 4.3.1). We emphasize that this dichotomous subdivision into two distinct physiographic landscape types is not realistic at a local scale where transitions are more discrete. For studies at finer scales we would not recommend the use of this relatively coarse subdivision.

\subsubsection{SOC distribution by soil types}

In general, the permafrost soils and organic soils dominate 0-3 m SOC storage in the northern circumpolar permafrost region, especially at depths below $1 \mathrm{~m}$ depth. This is in accordance with previous results from this region (e.g. Ping et al., 2008; Tarnocai et al., 2009) and reflects current understanding of the processes that lead to accumulation of SOC in permafrost region soils (cryoturbation, accumulation of peat and repeated deposition and stabilization of organic-rich material).

Because of their substantial areal extent and high mean SOC storage $\left(\mathrm{kg} \mathrm{Cm}^{-2}\right)$, cryoturbated mineral soils are important SOC reservoirs. Turbels south of the High Arctic region store $41 \%$ of SOC stocks with $31 \%$ areal coverage (Table 4). There are no significant differences in mean Turbel SOC storage between physiographic regions of thick and thin sedimentary overburden regions but there is notable variability in the data at all depths. Especially in areas of thin sediment overburden, low data availability (Table 1) combined with great natural variability leads to wider relative uncertainty ranges of estimates.

The mean SOC storage $\left(\mathrm{kgC} \mathrm{m}^{-2}\right)$ is highest in organic soils (Histosols and Histels; Table 2), and these soils also contribute greatly to total SOC stocks (both classes store $14 \%$ each of $0-3 \mathrm{~m}$ SOC stocks with only 5 and $7 \%$ areal coverage, respectively). Regions dominated by organic soils, such as the West Siberian Lowlands or the lower Mackenzie River basin, are especially SOC-rich across depths (Fig. 3). There is relatively large variability in SOC storage of organic soils across regions. Unexpectedly, the upper $2 \mathrm{~m}$ of Histosols in regions of thin sediment overburden have significantly higher SOC storage than Histosols from thick sediment areas (Fig. 2). Considering the low degree of replication for Histosols in areas of thin sediment overburden $(n=8)$, 
additional field observations are needed to further evaluate this result. This high estimated mean SOC storage of Histosols in thin sediment regions is heavily influenced by a few very SOC-rich pedons and should be interpreted with caution.

Mineral permafrost soils unaffected by cryoturbation (Orthels) differ greatly across regions. In areas with recurring deposition and stabilization of organic-rich sediment (alluvium, proluvium, colluvium or wind-blown deposits) very large SOC stocks have accumulated over long timescales (Schirrmeister et al., 2011b). In other cases, shallow, noncryoturbated permafrost soils in e.g. mountain regions store little SOC (Ping et al., 1998). In this study, Orthels in regions with thin sediments (corresponding to upland or montane areas) store little SOC while Orthels in regions with thick sediment have accumulated significant SOC stocks down to $3 \mathrm{~m}$ depth (Fig. 2).

In regions of discontinuous permafrost cover (commonly in areas of boreal forest), a large portion of the landscape is covered by non-permafrost mineral soils which also store significant amounts of SOC. Non-permafrost mineral soils cover $38 \%$ of the total permafrost region area and stores $15 \%$ of total $0-3 \mathrm{~m}$ SOC stocks. In the upper metre, upscaling is based on the 11 different non-permafrost mineral soil orders mapped in the NCSCDv2. Estimated mean SOC storage in this depth interval shows significant variability in estimates with a range from 1.7 to $25.2 \mathrm{~kg} \mathrm{Cm}^{-2}$ (Table 2). In the 1-2 $\mathrm{m}$ depth interval estimated SOC storage is $\sim 10 \mathrm{~kg} \mathrm{Cm}^{-2}$ in both thick and thin sediment regions. This remains unchanged below $2 \mathrm{~m}$ in thick sediment regions while there is significantly less SOC in thin sediment regions. A large fraction of SOC in these latter soils is stored in the top-soil within $\mathrm{O}$ and $\mathrm{A}$ horizons where high SOC storage may indicate accumulation of humified organic matter, charcoal, or char-mediated sorption in fire-prone boreal forests. Beneath $\mathrm{O}$ and $\mathrm{A}$ soil horizons, important mechanisms for stabilizing SOC in permafrost-free mineral soils include deep rooting, sorption of leached dissolved organic $\mathrm{C}$ to clay particles or formation of complexes with iron and/or aluminium. Lower SOC storage in deeper horizons reflects that these soils are less affected by $\mathrm{C}$ stabilization processes such as cryoturbation or repeated deposition typically found in permafrost or organic soils. The very low storage in nonpermafrost mineral soils of region with thin sediments is due to the influence from pedons in Alpine terrain with limited soil development where bedrock is typically encountered within the upper $3 \mathrm{~m}$.

\subsection{Estimated uncertainties and data gaps}

This study presents the first quantitative uncertainty ranges for estimates of SOC stocks in northern circumpolar permafrost region. The widest uncertainty ranges are associated with those same components that also Tarnocai et al. (2009) identified as being most uncertain. That study assigned low to very low confidence for estimates of SOC stocks stored in deep soil (1-3 m), Yedoma region deposits and deltaic deposits.

For $0-3 \mathrm{~m}$ soils and deltaic deposits the uncertainty ranges were calculated based on within-class variability of pedons (or alluvial deposit thickness) and areal/volumetric coverage of classes. For Yedoma region SOC stocks, the uncertainty ranges correspond to the 5 and 95 th percentiles of bootstrapped estimates. The former approach integrates all individual soil-horizons to the pedon level and assumes a (log)normal data distribution while the latter allows nonnormality, but also differs in that it does not integrate individual sediment layers or horizons at the site/pedon level. These updated estimates are based on collaborative databases where efforts have been made to collect data from across regions and from different research groups. Despite this, substantial regional data gaps remain such as in the High Arctic, central Siberia and many river deltas.

\subsubsection{Spatial distribution of pedons}

The spatial distribution of pedons used to estimate SOC stocks in the 1-3 m depth range is highly clustered (Fig. 1). For example, parts of Alaska and western Russia are well represented, but there are significant data gaps in central Asia, Scandinavia, Greenland, Svalbard and eastern Canada. There is a clear possibility that the available pedons are not truly representative for those areas where field data are lacking. This source of uncertainty is not addressed in this study but we acknowledge that adding more field-based data from under-sampled regions could substantially improve estimates. A previous comparisons between estimates of $0-1 \mathrm{~m}$ SOC stocks based on the NCSCD and local-scale studies revealed pronounced differences, especially for Turbels and organic soils (Kuhry et al., 2010). A way to potentially address this source of uncertainty in future studies is to assess the upscaled estimates against independent validation data sets. Such approaches could be applied across scale to address uncertainties from site scale to regional scales.

\subsubsection{Regional uncertainties of estimates for $0-3 \mathrm{~m}$ soils}

The estimates of SOC stocks in 1-3 m soils are based on a highly generalized upscaling scheme. Pedons are grouped based on soil characteristics (defined by absence/presence of permafrost, thick organic layers and cryoturbation) and mean SOC storage values are then assigned to large geographical regions (physiographic regions of thick/thin sediments, respectively). For the estimate of $0-1 \mathrm{~m}$ soils, a similar simplified scheme was applied to all NCSCD regions except Alaska and Canada (Tarnocai et al., 2009). In Alaska and Canada, SOC storage values were individually assigned to mapped soil series (Alaska) or soil names (Canada) from national soil inventories. Because of these methodological differences, there are some discrepancies across depths for 
estimates in Alaska and Canada, where 1-2 or 2-3 m soil layers are sometimes estimated to hold more SOC than the upper metre of soils. This applies to some areas in the western Hudson Bay lowlands and parts of the Canadian Arctic archipelago outside of the High Arctic zone. Clear trends of decreased SOC storage with depth (Fig. 2) indicate that these vertical patterns in SOC storage are not realistic.

The upscaling approach applied here relies on the assumption that our pedon data sets are accurate and unbiased samples of permafrost region soils (Hugelius, 2012). For some regions, the degree of replication in individual soil classes is very low (Table 1). To correct for potential errors arising from incomplete sample representation in regions of thin sedimentary overburden and the High Arctic region the representation error was estimated and included in the summative uncertainty ranges. The representation error of any class in an under-sampled region is estimated by extracting the variability from repeated subsampling of larger samples available from other regions. For example, we thus assume that Turbels in thick sediment regions are roughly equally variable as Turbels in thin sediment regions.

In the High Arctic region, there are very limited pedon data available and the current estimate is based on only eight pedons (six Orthels, one Histel and one Turbel), which were grouped together as Gelisols for calculations. Because of low SOC stocks, this region does not contribute much to the overall uncertainty of total estimates. However, due to the very limited field data and the large degree of generalization in some High Arctic soil maps (e.g. Svalbard and Greenland, see Hugelius et al., 2013b) these estimates must be regarded as preliminary and highly uncertain. Storage of SOC in cryoturbated and organic soils is often highly variable, and sample sizes of at least $>30$ is recommended (Hugelius, 2012). In the current estimate of SOC below $1 \mathrm{~m}$ depth, there is very poor representation of Turbels for thin sediment regions outside of the High Arctic ( $n=6$ and 2 for the 1-2 and $2-3 \mathrm{~m}$ depths, respectively). Based on currently available data, we cannot provide robust estimates of SOC storage in physiographic regions of thin sedimentary overburden or the High Arctic region. This is also reflected in wide uncertainty ranges for SOC stocks in these regions. Considering their large areal extent it is nevertheless important to provide assessments based on what little data are available. Further field sampling and/or data compilation will hopefully provide opportunities to refine these estimates.

\subsubsection{Differences between soil pedon databases and sampling biases}

For the 0-1 m depth interval, two independent sources of pedon data to estimate SOC storage $\left(\mathrm{kg} \mathrm{Cm}^{-2}\right)$ are available (pedon data set 1 used to calculate $0-1 \mathrm{~m}$ SOC stocks and pedon data set 2 used to calculate 1-3 m SOC stocks). While pedon data set 2 was not actually used in the quantification of 0-1 m SOC stocks, estimates are available for that depth range. If we assume that the two independent data sets are accurate samples of $0-1 \mathrm{~m}$ SOC stocks, there should be no significant differences between the data sets. We therefore infer that the significant differences in 0-1 $\mathrm{m}$ SOC storage between pedon data sets 1 and 2 could be an indication of sampling biases. Near-surface pedon SOC storage is correlated to SOC storage below $1 \mathrm{~m}$ depth (Hugelius et al., 2014) and any biases in $0-1 \mathrm{~m}$ SOC could therefore also affect our estimates for stocks below $1 \mathrm{~m}$ depth. Summarized for the whole permafrost region, there are no significant differences between the data sets for the Orthel and Histel classes, while Turbels and non-permafrost mineral soils may be biased high and Histosols biased low in pedon data set 2. Because data for pedon data set 1 are only available aggregated to the whole permafrost region, no statistical comparisons can be made at regional levels. Detailed comparisons reveal that in North America, pedon data set 2 is consistently estimating higher values than pedon data set 1 (data not shown). In other regions, there are no clear patterns and results differ across soil classes.

There is an indicated bias towards high SOC in Turbels of pedon data set 2. Closer examination of regional patterns reveals that this is largely due to very high SOC storage for Turbels in North America (at all depths). For Eurasian Turbels the pattern is opposite with higher estimates in pedon data set 1 . When subdivided following physiographic regions differences between the two data sets are small. The bulk of available North American Turbels are from the North Slope of Alaska (Fig. 1), where previous studies have also shown high mean SOC storage in cryoturbated soils (Michaelson et al., 1996; Ping et al., 1998; Johnson et al., 2011). In general, the available data in pedon data set 2 are geographically clustered (Fig. 1; Hugelius et al., 2013a) and more dispersed samples of pedons from across regions could reduce any biases introduced by clustered sampling.

Hugelius et al. (2013a) discuss a potential large bias for organic soils where targeted sampling campaigns may cause sites with thick peat deposits to be over-represented in data sets. To avoid such a bias, pedon data set 2 includes all sites with organic soils, even if data from the mineral subsoil were missing (data from mineral C-horizons below organic deposits were extrapolated to full depth or default values were applied). A closer examination of the available data on peat deposit thickness reveals that the peat depths in those sites, where no extrapolation was needed (i.e. where coring was pursued to great depths in the field), are not representative of the true depth distribution of peat deposits based on all available observations from organic soils. If only pedons without extrapolation are used, mean peat depths are overestimated by a factor 2 (Fig. 4). If only sites without extrapolation were used to calculate SOC stocks, the total SOC stock estimates for organic soils (Histosols and Histels) would increase from the current $302 \mathrm{Pg}$ to $338 \mathrm{Pg}$. The estimated error introduced by applying default values is on the order of $\pm 2 \mathrm{Pg}$ (calculated from the standard error of means of the applied default 
values and mean extrapolation depth of pedons). The use of sites where data on mineral sub-soils was extrapolated may be one factor contributing to the indicated low-bias of Histosols in pedon data set 2 when compared to pedon data set 1 .

It is difficult to assess the potential bias between pedon data sets 1 and 2 for non-permafrost mineral soils. There is a much larger replication for these soils in pedon data set 1 . However, estimated SOC storage for many pedons in data set 1 are from the global scale ISRIC database (Batjes, 1996; Table S1) including all Eurasian permafrost-free soils and North American Aridisols, Andisols and Ultisols. Because of this, the data used for much of the non-permafrost mineral soils in data set 1 are likely not truly representative of soils in the permafrost region.

\subsubsection{Data availability and uncertainty estimates for deltaic deposits}

The updated estimate of deltaic SOC storage confirms that a substantial stock of permafrost SOC is stored in these deposits, but it is also clear that more field observations are needed to produce robust estimates. The calculated CI ranges indicate that uncertainties are larger concerning alluvium depth than mean SOC storage value, but the observational base for both estimates are very small and from most major deltas no field observations are available (Table 5). The estimated uncertainty ranges include an approximation of representation errors caused by the limited sample sizes. However, these estimates cannot fully account for the fact that most deltas lack field data altogether. Because of these very limited databases these estimates must be considered as preliminary for those deltas where no data are available. Further, the estimates rely on the assumption that alluvial SOC contents measured in the near surface can be extrapolated to full depth and the reported uncertainty ranges assume a correct spatial extent of deltas and correct volumetric extent of water bodies and massive ice.

\subsubsection{Uncertainties and data gaps of estimates for Yedoma region deposits}

SOC stocks in intact Yedoma and perennially frozen thermokarst deposits are calculated based on bootstrapped analyses of data on deposit thickness, organic $\mathrm{C} \%$, bulk density (including segregated ice \%), and wedge-ice volume gathered from a total of 22 study areas sampled/described in the field. This approach reflects the variability of individual observations (i.e. analyses of discrete sediment samples or individual depth measurements), which is an effective way of estimating stocks with large inherent (spatial) variability. By estimating one mean based on 10000 single observation-based bootstrapping means, our single estimator's uncertainty is remarkably lower compared to Strauss et al. (2013). To further improve SOC stock calculation, sensitivity analysis revealed that enhanced data on ice wedge

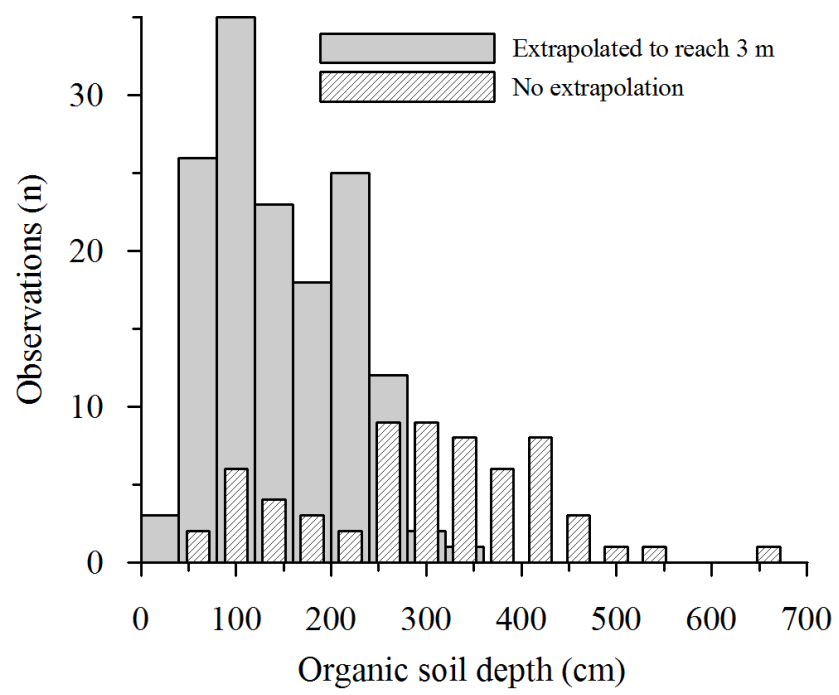

Figure 4. Histograms illustrating the depth-distribution of peat deposits (organic soil material) in Histosols and Histels of pedon data set 2 (bins $=40 \mathrm{~cm}$ depth). The graph shows separate histograms for pedons that were extrapolated to reach the full $3 \mathrm{~m}$ depth required for upscaling and pedons where no extrapolation was needed.

volume (Ulrich et al., 2014) and Yedoma deposit thickness will reduce uncertainties significantly.

Another potential source of uncertainty is the geographical extent of the Yedoma region, which is challenging to define discretely. As described in Strauss et al. (2013), the definition of the Yedoma region used here is based on estimates from Romanovskii (1993) for Siberia and Jorgenson et al. (2008) for Alaska. Moreover, we added $\sim 65000 \mathrm{~km}^{2}$ for regions with smaller known Yedoma occurrences (e.g. south of Taymyr Peninsula and Chukotka in Russia and the Yukon Territory in Canada). To describe the spatial fragmentation of Yedoma deposit remnants, we used a fragmented Yedoma coverage in the region of $30 \%$, whereas thermokarst basins with refrozen sediments cover $56 \%$. Existing thermokarst lakes and rivers were excluded, covering $14 \%$ of the region. To improve this simplified approach, an uncertainty reduction could be reached by implementing spatially explicit data of intact Yedoma distribution based on geological maps for Siberia (Grosse et al., 2013). Nevertheless, data for thermokarst deposit coverage and intact Yedoma coverage in the Taymyr lowlands, Chukotka, parts of Alaska and northwestern Canada are currently not available.

\subsubsection{Potential error sources not included in uncertainty estimates}

The uncertainty ranges calculated for this study are based on the assumption that the various areal extents of soil (sub)orders, deltas, intact Yedoma and thermokarst are correctly mapped. In all cases we thus assume that the maps are right and that spatial errors do not contribute to estimated 
uncertainties. A regional study of the Northern Usa River basin (Russian Arctic) showed that uncertainties from map errors were similar in magnitude as uncertainties from insufficient pedon representation or natural variability $(95 \%$ CI ranges both estimated at $\pm 8 \%$ for $0-1 \mathrm{~m}$ SOC stocks; Hugelius, 2012). Because no dedicated ground-truthing data set is available to assess the NCSCD soil maps that form the spatial base of upscaling SOC in 0-3 m soils, we cannot directly quantify this error. Small-scale maps (covering large geographic regions) do not necessarily have lower mapping accuracy than large-scale maps (covering small geographic regions), but because of the necessary generalization inherent in map-making, large-scale maps from local studies (such as the land cover maps used by Hugelius, 2012) are expected to have higher mapping precision. We would thus expect uncertainty from spatial errors in the maps used in this study to be equal to or greater than those found for the Northern Usa River basin (i.e. a $95 \% \mathrm{CI}$ of $\pm 8 \%$ or more). If we assume an uncertainty of $\pm 10 \%$ from spatial error component in all estimates, the propagated uncertainty range of the combined estimate of $1307 \mathrm{Pg}$ SOC would increase by $\sim \pm 30$ to $\sim \pm 200 \mathrm{Pg}$. However, to properly assess the spatial errors in permafrost region SOC stock estimates, comprehensive ground-truthing data sets for circumpolar soil classification maps, deltaic extent and Yedoma region extent are needed.

Imprecision in field or laboratory measurements (e.g., sample volume, bulk density or $\mathrm{C}$ content) are not accounted for in this study. The relative importance of such errors is expected to differ between different studies, scales and landscape types. Goidts et al. (2009) provide a comprehensive analysis and discussion of different sources of uncertainty in SOC stock estimates and their propagation in upscaling. They conclude that following upscaling to landscape scale, imprecision in laboratory measurements of rock mass fragments $(>2 \mathrm{~mm})$, SOC concentration (\%) and bulk density may propagate and cause substantial uncertainty in estimates. However, as this circumpolar estimate study combines field and laboratory data collected from a multitude of different sources over several decades, quantifying this uncertainty is currently not possible.

\subsection{Deposits with significant SOC stocks below 3 m depth}

This estimate of SOC stocks in the northern circumpolar permafrost region includes 0 to $3 \mathrm{~m}$ soils as well as deeper deltaic deposits and permafrost deposits in the Yedoma region. Other deposits with significant SOC stocks below $3 \mathrm{~m}$ depth have not been included. In many organic soils of the permafrost region, peat deposits extend below $3 \mathrm{~m}$ depth (e.g. Sheng et al., 2004; Tarnocai et al., 2005; Hugelius and Kuhry, 2009; Yu, 2012). Of the organic soils included in pedon data set 2 in this study, $17 \%$ sites have peat deposits extending below $3 \mathrm{~m}$ depth (Fig. 4) and these peat deposits are expected to store substantial SOC stocks in addition to what is included here.

The current estimate for deltaic deposits includes the 12 major deltas in the permafrost region (selection based on Walker, 1998), but all intermediate or small deltas are excluded. Presently, there is no data set summarizing the aerial extent of deltaic deposits in the northern circumpolar permafrost region, but a geospatial characterization of Arctic permafrost coastlines (Lantuit et al., 2012) shows significant occurrences of deltas along the Arctic coastline besides those included here. New data also reveal that, besides deltas and the Yedoma region, there are significant SOC stocks in other unconsolidated deeper Quaternary deposits of the permafrost region (Hugelius et al., 2011; Schirrmeister et al., 2011a; Ping et al., 2011; among others). Following the physiographic subdivision, $6.2 \times 10^{6} \mathrm{~km}^{2}$ of the permafrost region is characterized by thick sedimentary overburden (sediments deeper than 5-10 m; Brown et al., 2002). Deltaic deposits and the Yedoma region included in this study together cover ca. $1.5 \times 10^{6} \mathrm{~km}^{2}$. Any SOC stored in deposits below $3 \mathrm{~m}$ depth in the remaining ca. $5 \times 10^{6} \mathrm{~km}^{2}$ of thick sedimentary overburden remains unaccounted for.

\subsection{Potential vulnerability and remobilization of permafrost region SOC stocks}

The substantial SOC stocks of the northern permafrost region are vulnerable to thaw remobilization following permafrost degradation (Schuur et al., 2008, 2013). Key processes of permafrost degradation include active layer deepening, talik or thermokarst formation and thermal erosion (Schuur et al., 2008; Grosse et al., 2011). While active layer deepening mainly affects near-surface soils (Harden et al., 2012), taliks, thermokarst and thermal erosion can cause remobilization and potential mineralization of SOC stored at greater depths. Local-scale studies indicate that both active layer deepening and thermokarst (or thermoerosion) can affect substantial fractions of permafrost landscapes over decadal timescales (Jones et al., 2011, 2013; Hugelius et al., 2011, 2012; Sannel and Kuhry, 2011).

Both active layer SOC and permafrost is highly susceptible to impacts from wildfire (Harden et al., 2000), which has increased in severity and areal extent with recent warming (Turetsky et al., 2011). SOC stocks in the permafrost region may be reduced directly via combustion, or indirectly due to post-fire increases in soil temperature and decomposition (Harden et al., 2006; Mack et al., 2011). Fire-driven reductions in organic-horizon thickness also decreases subsoil insulation and cause active layer deepening, which can increase the amount of SOM susceptibly to decomposition in the unfrozen phase (O'Donnell et al., 2011).

Global-scale projections of greenhouse-gas emissions from permafrost deposits using Earth System Models (ESMs) demonstrate that inclusion of permafrost soil C stocks lead to the potential for a large positive climate 
feedback from the permafrost region (Koven et al., 2011; Schaefer et al., 2011; Burke et al., 2012a, b; Schneider von Deimling et al., 2012; MacDougall et al., 2012). These models are still simplified representations of permafrost carbon cycling and do not resolve high landscape spatial heterogeneity or account for many observed processes, such as thermokarst or post-fire dynamics. The complexity of ESMs also makes it difficult to assign mechanistic sources of model errors. In order to increase confidence in ESMs, it is necessary to better understand the controls on soil $\mathrm{C}$ by process, location, and depth so that observations can be used as a benchmark for these models. Extant ESM-based quantifications of the permafrost-climate feedback have not included SOC stocks of deltaic alluvium or Yedoma and the reduced estimates for these stocks would not affect published projected feedback magnitudes. Using a simplified modelling framework, Burke et al. (2012a) demonstrated that uncertainties in quantification of permafrost SOC stocks accounted for ca. half of the variability in ESM projections of increased global mean temperature associated with permafrost carbon thaw (excluding variability caused by different representative concentration pathway scenarios). Using similar approaches together with the quantified uncertainty ranges provided in this study could reveal the relative impact of large SOC estimate uncertainties on ESMs projections of the permafrost-climate feedback.

\section{Conclusions}

This study summarizes present knowledge regarding estimated size and variability of SOC stocks in $0-3 \mathrm{~m}$ soils, deltas and the Yedoma region across the northern circumpolar permafrost region. Combined estimated SOC stocks in this region are $1307 \mathrm{Pg}$ with an uncertainty range of $1140-1476 \mathrm{Pg}$. An estimated $999 \mathrm{Pg}$ of SOC is stored in permafrost terrain, of which $822 \mathrm{Pg}$ is perennially frozen.

There are substantial regional gaps in pedon data to assess SOC storage below $1 \mathrm{~m}$ depth. In particular, cryoturbated and organic (peatland) soils are highly variable and difficult to assess. The High Arctic bioclimatic zone and physiographic regions characterized by thin sedimentary overburden (areas of mountains, highlands, and plateaus) are poorly represented in the current pedon databases. Future field sampling to reduce these limitations should focus on the following observing strategies: (1) sampling soils in the full 0-3 m depth interval throughout the permafrost region, (2) sampling soils in regions of thin sedimentary overburden and the High Arctic, and (3) sampling soils away from current data clusters, particularly in Eurasia. The estimates of SOC stocks in deltaic alluvium and Yedoma region deposits are also based on very limited observational evidence. Improved estimates of deposit thicknesses, mean SOC content and massive ice content could greatly reduce uncertainties in these estimates.
It is important to note that the presented uncertainty ranges do not account for errors in upscaling maps or analytical uncertainties in laboratory measurements. To quantify uncertainties arising from errors in upscaling maps, groundtruthing data sets for soil classification maps, deltaic alluvium extent and Yedoma region extent are needed. We also stress that substantial pools of SOC not included in this present study are stored below $3 \mathrm{~m}$ depth in soils and in unconsolidated sediments outside of the Yedoma region and deltaic deposits. The size and potential thaw-vulnerability of these additional SOC pools remains to be determined.

We conclude that soils and sediments of the northern circumpolar permafrost region store large amounts of SOC $(\sim 1300 \mathrm{Pg})$ but that this revised estimate shows that the fraction of SOC that is perennially frozen $(\sim 800 \mathrm{Pg})$ is substantially smaller than previously estimated.

\section{The Supplement related to this article is available online at doi:10.5194/bg-11-6573-2014-supplement.}

Acknowledgements. We are grateful to $\mathrm{C}$. Tarnocai for providing pedon data as well as insightful comments and suggestions. We are grateful to two anonymous reviewers for providing detailed and insightful comments, especially regarding calculations of estimate uncertainties. This work was supported by grants from the International Permafrost Association, the EU 7th framework PAGE21 project, the Nordic Centres of Excellence DEFROST project, a grant of the Swedish Research Council as a part of the International Program CryoCARB and the Bolin Centre for Climate Research at Stockholm University. This effort is also a contribution to the Global Carbon Project of the Earth System Science Partnership, the Carbon Stocks in Permafrost regions Project of the International Permafrost Association and the Vulnerability of Permafrost Carbon Research Coordination Network under sponsorship of the National Science Foundation. The contributions of J. Strauss were funded by the Federal Ministry of Education and Research (01DM12011) and the German National Academic Foundation. The contributions of S. Zubrzycki were partly supported through the BMBF project "CarboPerm" (03G0836A), and partly supported through the Cluster of Excellence "CliSAP" (EXC177), Universität Hamburg, funded through the German Research Foundation (DFG). The contributions of G. Grosse were supported by a European Research Council Starting Grant (\#338335). The contributions of B. Elberling were supported by the Center for Permafrost, funded by the Danish National Research Foundation (CENPERM DNRF100). The contributions of G. J. Michaelson and C. L. Ping were supported by the USDA-Hatch project. The contributions of Z. C. Yu were supported by the US NSF (ARC-1107981).

Edited by: J.-A. Subke 


\section{References}

Aylsworth, J., Burgess, M., Desrochers, D., Duk-Rodkin, A., Robertson, T., and Traynor, J.: Surficial geology, subsurface materials, and thaw sensitivity of sediments, in: The physical environment of the Mackenzie valley, Northwest territories: A base line for the assessment of environmental change, edited by: Dyke, L. D. and Brooks, G. R., Geological Survey of Canada, Ottawa, 31-39, 2000.

Batjes, N. H.: Total carbon and nitrogen in the soils of the World, European J.. Soil Sci., 47, 151-164, 1996.

Brown, J., Ferrians, O. J., Heginbottom, J. A., and Melnikov, E. S.: Circum-Arctic map of permafrost and and ground-ice conditions, version 2, National Snow and Ice Data Center, Boulder, 2002.

Burke, E. J., Hartley, I. P., and Jones, C. D.: Uncertainties in the global temperature change caused by carbon release from permafrost thawing, The Cryosphere, 6, 1063-1076, doi:10.5194/tc6-1063-2012, 2012a.

Burke, E. J., Jones, C. D., and Koven, C. D.: Estimating the permafrost-carbon climate response in the CMIP5 climate models using a simplified approach, J. Climate, 26, 4897-4909, doi:10.1175/jcli-d-12-00550.1, 2012b.

Davidson, E. A. and Janssens, I. A.: Temperature sensitivity of soil carbon decomposition and feedbacks to climate change, Nature, 440, 165-173, 2006.

Goidts, E., Van Wesemael, B., and Crucifix, M.: Magnitude and sources of uncertainties in soil organic carbon (SOC) stock assessments at various scales, Eur. J. Soil Sci., 60, 723-739, doi:10.1111/j.1365-2389.2009.01157.x, 2009.

Grosse, G., Harden, J., Turetsky, M. R., McGuire, A. D., Camill, P., Tarnocai, C., Frolking, S., Schuur, E. A. G., Jorgenson, T., Marchenko, S., Romanovsky, V., Wickland, K. P., French, N., Waldrop, M. P., Bourgeau-Chavez, L., and Striegl, R. G.: Vulnerability of high-latitude soil organic carbon in North America to disturbance, J. Geophys. Res., 116, G00K06, doi:10.1029/2010JG001507, 2011.

Grosse, G., Robinson, J. E., Bryant, R., Taylor, M. D., Harper, W., DeMasi, A., Kyker-Snowman, E., Veremeeva, A., Schirrmeister, L., and Harden, J.: Distribution of late Pleistocene ice-rich syngenetic permafrost of the Yedoma suite in east and central Siberia, Russia, U.S. Geological Survey Open File Report, 1078, 37 pp., 2013.

Hammer, Ø., Harper, D. A. T., and Ryan, P. D.: PAST: Paleontological statistics software package for education and data analysis, Palaeontol. Electron., 4, 1-10, 2001.

Hammer, Ø., Harper, D. A. T., and Ryan, P. D.: Past: Paleontological statistics software package for education and data analysis, Palaeontol. Electron., 4, 1-10, 2012.

Harden, J. W., Meier, R., Silapaswan, C., Swanson, D. K., and McGuire, A. D.: Soil drainage and its potential for influencing wildfires in Alaska, in Studies by the US Geological Survey in Alaska, J. Galloway, Editor, US Geol. Surv. Profess. Paper, 1678, 139-144, 2003

Harden, J. W., Manies, K. L., Turetsky, M. R., and Neff, J. C.: Effects of wildfire and permafrost on soil organic matter and soil climate in interior Alaska, Global Change Biol., 12, 2391-2403, doi:10.1111/j.1365-2486.2006.01255.x, 2006.

Harden, J. W., Koven, C. D., Ping, C. L., Hugelius, G., McGuire, A. D., Camill, P., Jorgenson, T., Kuhry, P., Michaelson, G. J., O’Donnell, J. A., Schuur, E. A. G., Tarnocai, C., Johnson, K., and
Grosse, G.: Field information links permafrost carbon to physical vulnerabilities of thawing, Geophys. Res. Lett., 39, L15704, doi:10.1029/2012g1051958, 2012.

Heginbottom, J. A.: Permafrost distribution and ground ice in surficial materials, in: The physical environment of the Mackenzie valley, Northwest Territories: A base line for the assessment of environmental change, edited by: Dyke, L. D. and Brooks, G. R., Geological Survey of Canada, Ottawa, 31-39, 2000.

Heginbottom, J. A., Brown, J., Ferrians, O. J., and Melnikov, E. S.: Circum-Arctic map of permafrost and ground-ice conditions, in: Sixt International Conference on Permafrost, Beijing, 1132-1136, 1993.

Horwath Burnham, J. and Sletten, R. S.: Spatial distribution of soil organic carbon in northwest Greenland and underestimates of high Arctic carbon stores, Global Biogeochem. Cy., 24, GB3012, doi:10.1029/2009gb003660, 2010.

Houghton, R. A.: Balancing the global carbon budget, Annu. Rev. Earth Pl. Sc., 35, 313-347, doi:10.1146/annurev.earth.35.031306.140057, 2007.

Hugelius, G.: Spatial upscaling using thematic maps: An analysis of uncertainties in permafrost soil carbon estimates, Global Biogeochem. Cy., 26, GB2026, doi:10.1029/2011gb004154, 2012.

Hugelius, G. and Kuhry, P.: Landscape partitioning and environmental gradient analyses of soil organic carbon in a permafrost environment, Global Biogeochem. Cy., 23, GB3006, doi:10.1029/2008gb003419, 2009.

Hugelius, G., Virtanen, T., Kaverin, D., Pastukhov, A., Rivkin, F., Marchenko, S., Romanovsky, V., and Kuhry, P.: High-resolution mapping of ecosystem carbon storage and potential effects of permafrost thaw in periglacial terrain, European Russian Arctic, J.Geophys. Res., 116, G03024, doi:10.1029/2010jg001606, 2011.

Hugelius, G., Routh, J., Kuhry, P., and Crill, P.: Mapping the degree of decomposition and thaw remobilization potential of soil organic matter in discontinuous permafrost terrain, J. Geophys. Res.: Biogeosciences, 117, G02030, doi:10.1029/2011jg001873, 2012.

Hugelius, G., Bockheim, J. G., Camill, P., Elberling, B., Grosse, G., Harden, J. W., Johnson, K., Jorgenson, T., Koven, C. D., Kuhry, P., Michaelson, G., Mishra, U., Palmtag, J., Ping, C.-L., O’Donnell, J., Schirrmeister, L., Schuur, E. A. G., Sheng, Y., Smith, L. C., Strauss, J., and Yu, Z.: A new data set for estimating organic carbon storage to $3 \mathrm{~m}$ depth in soils of the northern circumpolar permafrost region, Earth Syst. Sci. Data, 5, 393-402, doi:10.5194/essd-5-393-2013, 2013a.

Hugelius, G., Tarnocai, C., Broll, G., Canadell, J. G., Kuhry, P., and Swanson, D. K.: The Northern Circumpolar Soil Carbon Database: spatially distributed datasets of soil coverage and soil carbon storage in the northern permafrost regions, Earth Syst. Sci. Data, 5, 3-13, doi:10.5194/essd-5-3-2013, 2013 b.

Hugelius, G., Strauss, J., Zubrzycki, S., Harden, J., Schuur, E. A. G., Ping, C.-L., Schirrmeister, L., Grosse, G., Michaelson, G., Koven, C., O’Donnel, J., Elberling, B., Mishra, U., Camill, P., Yu, Z., Palmtag, J., and Kuhry, P.: Improved estimates show large circumpolar stocks of permafrost carbon while quantifying substantial uncertainty ranges and identifying remaining data gaps, Biogeosciences Discuss., 11, 4771-4822, doi:10.5194/bgd-114771-2014, 2014. 
Johnson, K. D., Harden, J., McGuire, A. D., Bliss, N. B., Bockheim, J. G., Clark, M., Nettleton-Hollingsworth, T., Jorgenson, M. T., Kane, E. S., Mack, M., O'Donnell, J., Ping, C.-L., Schuur, E. A. G., Turetsky, M. R., and Valentine, D. W.: Soil carbon distribution in Alaska in relation to soil-forming factors, Geoderma, 167-168, 71-84, doi:10.1016/j.geoderma.2011.10.006, 2011.

Johnston, G. H. and Brown, R. J. E.: Stratigraphy of the Mackenzie river delta, Northwest Territories, Canada, Bull. Geol. Soc. Am., 76, 103-112, doi:10.1130/00167606(1965)76[103:sotmrd]2.0.co;2, 1965.

Jones, B. M., Grosse, G., Arp, C. D., Jones, M. C., Walter Anthony, K. M., and Romanovsky, V. E.: Modern thermokarst lake dynamics in the continuous permafrost zone, northern Seward peninsula, Alaska, J. Geophys. Res., 116, G00M03, doi:10.1029/2011JG001666, 2011.

Jones, M. C., Booth, R. K., Yu, Z. C., and Ferry, P.: A 2200year record of permafrost dynamics and carbon cycling in a collapse-scar bog, interior Alaska, Ecosystems, 16, 1-19, doi:10.1007/s10021-012-9592-5, 2013.

Jorgenson, M. T., Yoshikawa, K., Kanveskiy, M., Shur, Y., Romanovsky, V., Marchenko, S., Grosse, G., Brown, J., and Jones, B.: Permafrost characteristics of Alaska, in: Proceedings of the Ninth International Conference on Permafrost, 3, 121-122, 2008.

Koven, C. D., Ringeval, B., Friedlingstein, P., Ciais, P., Cadule, P., Khvorostyanov, D., Krinner, G., and Tarnocai, C.: Permafrost carbon-climate feedbacks accelerate global warming, P. Natl. Acad Sci. USA, 108, 14769-14774, doi:10.1073/pnas.1103910108, 2011.

Kuhry, P., Dorrepaal, E., Hugelius, G., Schuur, E. A. G., and Tarnocai, C.: Potential remobilization of belowground permafrost carbon under future global warming, Permafrost Periglac., 21, 208-214, doi:10.1002/ppp.684, 2010.

Kuhry, P., Grosse, G., Harden, J. W., Hugelius, G., Koven, C. D., Ping, C. L., Schirrmeister, L., and Tarnocai, C.: Characterisation of the permafrost carbon pool, Permafrost Periglac., 24, 146-155, doi:10.1002/ppp.1782, 2013.

Lantuit, H., Overduin, P. P., Couture, N., Wetterich, S., Aré, F., Atkinson, D., Brown, J., Cherkashov, G., Drozdov, D. S., Forbes, D. L., Graves-Gaylord, A., Grigoriev, M., Hubberten, H.-W., Jordan, J., Jorgenson, T., Ødegård, R. S., Ogorodov, S., Pollard, W. H., Rachold, V., Sedenko, S., Solomon, S., Steenhuisen, F., Streletskaya, I., and Vasiliev, A. A.: The arctic coastal dynamics database: A new classification scheme and statistics on Arctic permafrost coastlines, Estuar. Coast., 35, 383-400, doi:10.1007/s12237-010-9362-6, 2012.

MacDougall, A. H., Avis, C. A., and Weaver, A. J.: Significant contribution to climate warming from the permafrost carbon feedback, Nat. Geosci., 5, 719-721, doi:10.1038/ngeo1573, 2012.

Mack, M. C., Bret-Harte, M. S., Hollingsworth, T. N., Jandt, R. R., Schuur, E. A. G., Shaver, G. R., and Verbyla, D. L.: Carbon loss from an unprecedented Arctic tundra wildfire, Nature, 475, 489-492, doi:10.1038/nature10283, 2011.

Michaelson, G. J., Ping, C., and Kimble, J.: Carbon storage and distribution in tundra soils of Arctic Alaska, USA, Arctic Alpine Res., 414-424, doi:10.2307/1551852, 1996.

Mishra, U., Jastrow, J., Matamala, R., Hugelius, G., Koven, C., Harden, J., Ping, C., Michaelson, G., Fan, Z., and Miller, R.: Empirical estimates to reduce modeling uncertainties of soil organic carbon in permafrost regions: A review of re- cent progress and remaining challenges, Environ. Res. Lett., 8, 035020, doi:10.1088/1748-9326/8/3/035020, 2013.

O’Donnell, J. A., Harden, J. W., McGuire, A. D., Kanevskiy, M. Z., Jorgenson, M. T., and $\mathrm{Xu}, \mathrm{X}$.: The effect of fire and permafrost interactions on soil carbon accumulation in an upland black spruce ecosystem of interior Alaska: Implications for post-thaw carbon loss, Glob. Change Biol., 17, 1461-1474, doi:10.1111/j.1365-2486.2010.02358.x, 2011.

Ping, C. L., Bockheim, J. G., Kimble, J. M., Michaelson, G. J., and Walker, D. A.: Characteristics of cryogenic soils along a latitudinal transect in Arctic Alaska, J. Geophys. Res., 103, 28917-28928, doi:10.1029/98jd02024, 1998.

Ping, C. L., Michaelson, G. J., Jorgenson, M. T., Kimble, J. M., Epstein, H., Romanovsky, V. E., and Walker, D. A.: High stocks of soil organic carbon in the North American Arctic region, Nat. Geosci., 1, 615-619, 2008.

Ping, C.-L., Michaelson, G. J., Guo, L., Jorgenson, M. T., Kanevskiy, M., Shur, Y., Dou, F., and Liang, J.: Soil carbon and material fluxes across the eroding Alaska Beaufort Sea coastline, J. Geophys. Res., 116, G02004, doi:10.1029/2010jg001588, 2011.

R Core Team: A language and environment for statistical computing, R Foundation for Statistical Computing, Vienna, Austria, ISBN 3-900051-07-0, http://www.R-project.org/, 2012.

Roddick, J. C.: Generalized numerical error analysis with applications to geochronology and thermodynamics, Geochim. Cosmochim. Ac., 51, 2129-2135, doi:10.1016/00167037(87)90261-4, 1987.

Romanovskii, N. N.: Fundamentals of cryogenesis of lithosphere, Moscow University Press, Moscow, 336 pp., 1993.

Sannel, A. B. K. and Kuhry, P.: Warming-induced destabilization of peat plateau/thermokarst lake complexes, J. Geophys. Res., 116, G03035, doi:10.1029/2010jg001635, 2011.

Schaefer, K., Zhang, T., Bruhwiler, L., and Barrett, A. P.: Amount and timing of permafrost carbon release in response to climate warming, Tellus B, 63, 165-180, doi:10.1111/j.16000889.2011.00527.x, 2011.

Schirrmeister, L., Grosse, G., Schnelle, M., Fuchs, M., Krbetschek, M., Ulrich, M., Kunitsky, V., Grigoriev, M., Andreev, A., Kienast, F., Meyer, H., Babiy, O., Klimova, I., Bobrov, A., Wetterich, S., and Schwamborn, G.: Late Quaternary paleoenvironmental records from the western Lena delta, Arctic Siberia, Palaeogeogr. Palaeocl., 299, 175-196, doi:10.1016/j.palaeo.2010.10.045, 2011 a.

Schirrmeister, L., Grosse, G., Wetterich, S., Overduin, P. P., Strauss, J., Schuur, E. A. G., and Hubberten, H.-W.: Fossil organic matter characteristics in permafrost deposits of the northeast Siberian Arctic, J. Geophys. Res., 116, G00M02, doi:10.1029/2011jg001647, 2011b.

Schirrmeister, L., Kunitsky, V., Grosse, G., Wetterich, S., Meyer, H., Schwamborn, G., Babiy, O., Derevyagin, A., and Siegert, C.: Sedimentary characteristics and origin of the late Pleistocene ice complex on north-east Siberian Arctic coastal lowlands and islands - a review, Quatern. Int., 241, 3-25, doi:10.1016/j.quaint.2010.04.004, 2011c.

Schneider von Deimling, T., Meinshausen, M., Levermann, A., Huber, V., Frieler, K., Lawrence, D. M., and Brovkin, V.: Estimating the near-surface permafrost-carbon feedback on global warming, Biogeosciences, 9, 649-665, doi:10.5194/bg-9-649-2012, 2012. 
Schuur, E. A. G., Bockheim, J., Canadell, J. G., Euskirchen, E., Field, C. B., Goryachkin, S. V., Hagemann, S., Kuhry, P., Lafleur, P. M., and Lee, H.: Vulnerability of permafrost carbon to climate change: Implications for the global carbon cycle, BioScience, 58, 701-714, doi:10.1641/B580807, 2008.

Schuur, E. A. G., Abbott, B. W., Bowden, W. B., Brovkin, V., Camill, P., Canadell, J. G., Chanton, J. P., Chapin III, F. S., Christensen, T. R., Ciais, P., Crosby, B. T., Czimczik, C. I., Grosse, G., Harden, J., Hayes, D. J., Hugelius, G., Jastrow, J. D., Jones, J. B., Kleinen, T., Koven, C. D., Krinner, G., Kuhry, P., Lawrence, D. M., McGuire, A. D., Natali, S. M., O’Donnell, J. A., Ping, C. L., Riley, W. J., Rinke, A., Romanovsky, V. E., Sannel, A. B. K., Schädel, C., Schaefer, K., Sky, J., Subin, Z. M., Tarnocai, C., Turetsky, M. R., Waldrop, M. P., Walter Anthony, K. M., Wickland, K. P., Wilson, C. J., and Zimov, S. A.: Expert assessment of vulnerability of permafrost carbon to climate change, Climatic Change, 119, 359-374, doi:10.1007/s10584013-0730-7, 2013.

Schwamborn, G., Rachold, V., Schneider, W., Grigoriev, M., and Nixdorf, U.: Ground Penetrating Radar and Shallow Seismic - Stratigraphic and Permafrost Investigations of Lake Nikolay, Lena Delta, Arctic Siberia, in: Proceedings of the Eighth International Conference on Ground Penetrating Radar GPR2000, Gold Coast, Australia, 23-26 May 2000, SPIE 4084, 783-789, 2000.

Schwamborn, G., Rachold, V., and Grigoriev, M. N.: Late Quaternary sedimentation history of the Lena delta, Quatern. Int., 89, 119-134, doi:10.1016/S1040-6182(01)00084-2, 2002.

Sheng, Y., Smith, L. C., MacDonald, G. M., Kremenetski, K. V., Frey, K. E., Velichko, A. A., Lee, M., Beilman, D. W., and Dubinin, P.: A high-resolution GIS-based inventory of the west Siberian peat carbon pool, Global Biogeochem. Cy., 18, GB3004, doi:10.1029/2003gb002190, 2004.

Smith, I. R.: The seismic shothole drillers' log database and GIS for Northwest Territories and northern Yukon: An archive of near-surface lithostratigraphic surficial and bedrock geology data, Geological Survey of Canada, Open File Report 6833, doi:10.4095/288754, 2011.

Smith, L. C., Sheng, Y., MacDonald, G. M., and Hinzman, L. D.: Disappearing Arctic lakes, Science, 308, 1429, doi:10.1126/science.1108142, 2005.

Smith, S. L., Burgess, M. M., Chartrand, J., and Lawrence, D. E.: Digital borehole geotechnical database for the Mackenzie Valley/Delta region, Geological Survey of Canada, Open File Report 4924, 30 pp., 2005.

Soil Survey Staff: Soil taxonomy: A basic system of soil classification for making and interpreting soil surveys, 2nd Edn., United States Department of Agriculture, Washington, 869 pp., 1999.

Strauss, J., Schirrmeister, L., Wetterich, S., Borchers, A., and Davydov, S. P.: Grain-size properties and organic-carbon stock of Yedoma ice complex permafrost from the Kolyma lowland, northeastern Siberia, Global Biogeochem. Cy., 26, GB3003, doi:10.1029/2011GB004104, 2012.
Strauss, J., Schirrmeister, L., Grosse, G., Wetterich, S., Ulrich, M., Herzschuh, U., and Hubberten, H.-W.: The deep permafrost carbon pool of the Yedoma region in Siberia and Alaska, Geophys. Res. Lett., 40, 6165-6170, doi:10.1002/2013GL058088, 2013.

Tarnocai, C. and Stolbovoy, V.: Northern peatlands: Their characteristics, development and sensitivity to climate change, in: Peatlands: Evolution and records of environmental and climate changes, edited by: Martini, I. P., Martìnez Cortizas, A., and Chesworth, W., Elsevier, Amsterdam, 17-51, 2006.

Tarnocai, C., Kettles, I. M., and Lacelle, B.: Peatlands of Canada database, Agriculture and Agri-Food Canada, Ottawa, 2005.

Tarnocai, C., Canadell, J. G., Schuur, E. A. G., Kuhry, P., Mazhitova, G., and Zimov, S.: Soil organic carbon pools in the northern circumpolar permafrost region, Global Biogeochem. Cy., 23, GB2023, doi:10.1029/2008GB003327, 2009.

Taylor, A. E., Dallimore, S. R., and Judge, A. S.: Late Quaternary history of the Mackenzie-Beaufort region, Arctic Canada, from modelling of permafrost temperatures. 2. The Mackenzie Delta-Tuktoyaktuk Coastlands, Can. J. Earth Sci., 33, 62-71, doi:10.1139/e96-007, 1996.

Turetsky, M. R., Kane, E. S., Harden, J. W., Ottmar, R. D., Manies, K. 'L., Hoy, E., and Kasischke, E. S.: Recent acceleration of biomass burning and carbon losses in Alaskan forests and peatlands, Nat. Geosci., 4, 27-31, doi:10.1038/ngeo1027, 2011.

Ulrich, M., Grosse, G., Strauss, J., and Schirrmeister, L.: Quantifying wedge-ice volumes in yedoma and thermokarst basin deposits, Permafrost Periglac., 25, 151-161, doi:10.1002/ppp.1810, 2014.

Walker, H. J.: Arctic deltas, J. Coastal Res., 14, 718-738, 1998.

Yi, S., Manies, K., Harden, J., and McGuire, A. D.: Characteristics of organic soil in black spruce forests: Implications for the application of land surface and ecosystem models in cold regions, Geophys. Res. Lett., 36, L05501, doi:10.1029/2008g1037014, 2009.

Yu, Z. C.: Northern peatland carbon stocks and dynamics: a review, Biogeosciences, 9, 4071-4085, doi:10.5194/bg-9-40712012, 2012.

Zimov, S. A., Davydov, S. P., Zimova, G. M., Davydova, A. I., Schuur, E. A. G., Dutta, K., and Chapin, F. S.: Permafrost carbon: Stock and decomposability of a globally significant carbon pool, Geophys. Res. Lett., 33, L20502, doi:10.1029/2006GL027484, 2006.

Zubrzycki, S., Kutzbach, L., Grosse, G., Desyatkin, A., and Pfeiffer, E.-M.: Organic carbon and total nitrogen stocks in soils of the Lena River Delta, Biogeosciences, 10, 3507-3524, doi:10.5194/bg-10-3507-2013, 2013. 